2014

\title{
Ex Ante Versus Ex Post Deliberations: Two Models of Judicial Deliberations in Courts of Last Resort
}

\author{
Mathilde Cohen \\ University of Connecticut School of Law
}

Follow this and additional works at: https://opencommons.uconn.edu/law_papers

Part of the Comparative and Foreign Law Commons, Law and Psychology Commons, and the Organizations Law Commons

\section{Recommended Citation}

Cohen, Mathilde, "Ex Ante Versus Ex Post Deliberations: Two Models of Judicial Deliberations in Courts of Last Resort" (2014). Faculty Articles and Papers. 286.

https://opencommons.uconn.edu/law_papers/286 


\section{HEINONLINE}

Citation: 62 Am. J. Comp. L. 9512014

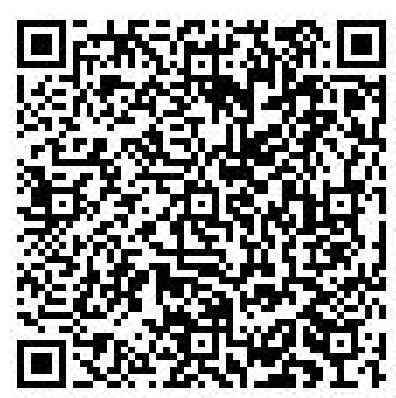

Content downloaded/printed from

HeinOnline (http://heinonline.org)

Mon Aug 15 16:49:42 2016

-- Your use of this HeinOnline PDF indicates your acceptance of HeinOnline's Terms and Conditions of the license agreement available at http://heinonline.org/HOL/License

-- The search text of this PDF is generated from uncorrected OCR text.

-- To obtain permission to use this article beyond the scope of your HeinOnline license, please use:

https://www.copyright.com/ccc/basicSearch.do?

\&operation $=$ go\&search Type $=0$

\&lastSearch $=$ simple\&all $=$ on\&titleOrStdNo=0002-919X 


\section{Ex Ante Versus Ex. Post Deliberations: Two Models of Judicial Deliberations in Courts of Last Resort $\dagger$}

This Article discusses supreme and constitutional courts' internal organizational cultures, that is, the way in which justices organize their work and establish informal decision-making norms. Courts of last resort are often presented as exemplary deliberative institutions. The conference meeting, which convenes judges in quiet seclusion to debate, has been glorified as the most significant step in a court's decision-making process. Based in part on qualitative empirical research, I argue, however, that French, American, and European justices may not deliberate in the full sense that deliberative democrats have theorized.

The Article distinguishes two types of high court deliberations, which I call the "ex ante" and the "ex post" models. In the first model, prevalent in the French and European courts, judges draft and deliberate the court's merits opinion before the case is orally argued and scheduled for the conference meeting. In other words, cases are decided before being decided. The second model is typical of AngloAmerican supreme courts, in particular the United States Supreme Court; in this model, justices do most of the deliberative work after the case has been orally argued and a vote on the merits has taken place at the conference. In other words, cases are decided after being decided.

Despite different judicial cultures, one common theme is that in both ex ante and ex post courts, judges tend to decide cases through a succession of multiple small group interactions involving non-judicial personnel rather than a single prolonged face-to-face deliberation. The upshot of the Article is the formulation of a dual-influence hypothesis: a court's style of judicial opinions may form deliberations as much as deliberations shape opinions.

* Associate Professor of Law and Robert D. Glass Scholar, University of Connecticut School of Law. I am grateful to the lively audiences at the Pace Law Faculty Workshop, the 2014 AALS Section on Comparative Law Works-in-Progress Program, and the 2014 Comparative Law Works-in-Progress Workshop held at UCLA. I have received extremely helpful comments and criticism from an anonymous reviewer as well as from Erin Delaney, Rick Kay, Kim Lane Scheppele, and Seana Shiffrin. I am grateful for the generous support of the University of Connecticut School of Law.

$\dagger$ DOI http://dx.doi.org/10.5131/AJCL.2014.0028 


\section{INTRODUCTION}

This Article discusses supreme and constitutional courts' internal organizational cultures, by which I mean the way in which judges organize their work and establish informal decision-making norms. ${ }^{1}$ Contrary to current orthodoxy in legal and political science scholarship, I argue that these courts may not be exemplary deliberative institutions. ${ }^{2}$ In Political Liberalism, John Rawls described courts, especially high courts, as paragons of democratic deliberation. He famously declared that "in a constitutional regime with judicial review, public reason is the reason of its supreme court." 3 The authority of courts is supposed, according to deliberative theorists, to rest in large part on the qualities of judicial deliberations-the exchange of reasons and arguments that takes place both behind closed doors, in the conference room, and in the public forum, through the publication of opinions linking a court's decisions to sources of legal or moral authority ${ }^{4}$ Based in part on exploratory qualitative empirical research, this Article argues that in practice French, American, and European justices ${ }^{5}$ may not deliberate in the full sense of "deliberation" that

1. Symbolic management, or the management of organizational culture, has been described as a mechanism that directs behavior through shared values, norms, and goals. See generally ROBERT K. MERTon, Social TheORY AND Social StruCture (1949).

2. I use the expressions "courts of last resort" and "high courts" interchangeably to designate both supreme and constitutional courts, whether domestic or regional. While the U.S. Supreme Court is the highest court of appeals for constitutional as well as other issues, the other courts covered in this Article are more specialized. In France, there is a sharp distinction between the two supreme courts (the Conseil d'Etat, the highest court of appeals for public law, and the Cour de cassation, the highest court of appeals for private law) on the one hand, and on the other hand, the specialized constitutional court (the Conseil constitutionnel, which is the only court empowered to engage in (constitutional) judicial review of legislation and executive actions). The European Court of Human Rights and the Court of Justice of the European Union are supranational regional courts, but they have arguably become akin to international constitutional courts. Although neither European court is technically a constitutional court, they both engage in extensive constitutional review based on written instruments, respectively the European Convention for the Protection of Human Rights and the European Treaties, in order to decide whether a state is in violation of these international instruments. In addition, the Court of Justice of the European Union is the highest court in the European Union for matters of EU law. The Article occasionally refers to the U.K. Supreme Court, which is more limited in its powers of judicial review than the U.S. Supreme Court given that it is theoretically unable to review the constitutionality of legislation. See U.K. Supreme Court, Practice Direction 10, http://www.supremecourt.uk/procedures/practice-direction-10.html.

3. See John Rawls, Political Liberalism 231 (1993).

4. See, e.g., John Ferejohn \& Pasquale Pasquino, Constitutional Courts as Deliberative Institutions: Towards an Institutional Theory of Constitutional Justice, in Constitutional Justice, East and West: Democratic legitimacy and Constitutional Courts in Post-Communist Europe in a Comparative Perspective 22 (Wojciech Sadurski ed., 2002) (describing constitutional courts as deliberative institutions whose legitimacy depends on persuasive reason-giving).

5. Throughout the Article, I use the words "judges" and "justices" interchangeably to refer to the judicial personnel of courts of last resort. 
deliberative democrats such as John Rawls or Joshua Cohen have theorized. ${ }^{6}$

What is deliberation, according to deliberative theory, and why is it desirable? Deliberative theorists often oppose two modes of decision-making: voting versus deliberation. Voting proceeds by aggregating individual preferences. It does not require that voters debate among themselves or attempt to justify their preferences to one another. Voting mechanisms produce a consensus on questions of common concern, but they leave individual opinions unchanged. In contrast, deliberation is an exercise in mutual justification. During a deliberation, participants must present and justify their respective judgments so as to reach agreement on a common decision. The discussion must in principle take place face-to-face, with all participants present and enjoying equal opportunities to express their views. ${ }^{7}$ The superiority of deliberation is supposed to derive from the fact that it produces decisions which are the outcome of an actual convergence of individual judgments.

My research suggests, however, that courts of last resort do not consistently follow this pattern. Despite very different internal organizational cultures in place in Anglo-American and continental European courts, I have been struck by one commonality. In both judicial cultures, there is little face-to-face deliberation involving the entire court, and it is often not the case that all participants have equal opportunities to influence decisions. The two cultures diverge, however, as to the timing of deliberation. At the French and the European high courts, ${ }^{8}$ judges frequently decide cases in advance of the established forum for deliberation, i.e., the conference meeting. At the U.S. Supreme Court, justices characteristically decide cases after the conference meeting. Although there are variations in the work methods of the courts I studied, and within each court, from panel to panel and from judge to judge, two broad trends have emerged. This Article thus identifies two ideal types of high court decision-making,

6. See RawLs, supra note 3. See also Joshua Cohen, Deliberation and Democratic Legitimacy, in Deliberative DemocracY 67-92 (James Bohman \& William Rehg eds., 1997). But see Maya Sen, Courting Deliberation: An Essay on Deliberative Democracy in the American Judicial System, 27 Notre Dame J.L. Ethics \& PUB. Pol'y 303 (2013) (critiquing the deliberative depiction of the U.S. Supreme Court through the use of political science models, which have shown that judges are strategic and use zero-sum, quid pro quo bargaining).

7. Face-to face meetings are those in which participants communicate by talking, listening, and observing nonverbal behavior, and in which there is no lag between the sending and receiving of communication signals.

8. Neither the European Court of Human Rights nor the Court of Justice of the European Union technically count as "Continental" courts, since they include common law countries and have been, to some extent, modeled and influenced by both civil law and common law principles and procedures. However, part of my argument rests on the claim that, by and large, the Continental judicial model-and in particular the French model-has prevailed in terms of the internal organizational culture at the two European courts. 
which I call the "ex ante" and the "ex post" models. ${ }^{9}$ Neither model is all or nothing, as most courts can be characterized as falling along a continuum between the two poles. But each model has its paradigmatic cases.

In the ex ante model, prevalent at the French and European courts, judges engage in what I refer to as "pre-deliberations." Typically, a court member called the "reporting judge" (juge rapporteur in French) is assigned the management of a case. The reporting judge's main task is to propose a disposition and draft an opinion before the oral argument and conference meeting take place. As a result, the conference focuses not so much on how the court, as a collective entity, should decide the case, but rather on whether or not other panel members will sign off on an already fully written opinion, which has previously been circulated and discussed. In other words, cases are decided before being decided.

The ex post model is typical of the United States Supreme Court. In that model, justices engage in what I call "post-deliberations." They do most of the decision-making work after the oral argument and conference meeting have taken place. In principle, for each case, all deciding justices receive briefs and have the opportunity to read and analyze them before the conference is convened. The conference discussion, however, is usually skeletal. A real debate will not be attempted for most cases. The purpose of the conference is typically twofold: to quickly determine which outcome the majority favors and to assign the task of writing an opinion to one or several justices. It is to the opinion writers that conference participants allocate the authority and competence to instigate a conversation among the other justices and thereby shape the court's reasoning. In other words, cases are decided after being decided.

The Article does not take a normative stance on the two models proposed. My aim is neither to deplore the fact that courts of last resort fail to exhibit all of the deliberative traits praised by deliberative democrats nor to propose an alternative decision-making scheme. Rather, my primary goal is to provide an in-depth description of the way in which a few courts decide cases and to map out a typology of internal organizational judicial cultures. ${ }^{10}$ Different courts have elaborated different ways of dealing with disagreement among justices. These approaches may not always be truly "deliberative," but, as we will see, they seem to work inasmuch as they

9. I use the Weberian concept of ideal type as a constructed model employed to approximate reality by selecting and accentuating certain traits. See Max Weber, $O b$ jectivity in Social Science and Social Policy, reprinted in The Methodology OF THE Soclal Sciences 90 (Edward A. Shils \& Henry A. Finch eds. \& trans., 1949).

10. See generally Clifford GeERTz, The INTERPRETation OF Cultures (1973) (on the idea of an interpretive theory of culture which can be channeled through "thick" descriptions). 
facilitate the settling of controversial cases while allowing judges to express their viewpoints.

The upshot of the Article is the formulation of a dual-influence hypothesis. I hypothesize that a legal culture's style of judicial opinions forms court deliberations as much as deliberations shape opinions. If judges must by law issue a single, unsigned collegiate judgment and are prohibited or discouraged from writing separate opinions, we can expect to observe consequences in their court's internal organization. For instance, they will probably need to deliberate in advance of the conference meeting to ensure that a majority will support the court's draft opinion on conference day. But if, as in the Unites States, each justice is individually responsible for her explanations, there might be an inclination to deliberate after the conference meeting up until a compromise opinion (or series of opinions) has been agreed upon.

A few words on methods are in order. I describe my methodology as "qualitative comparative legal research," by which I mean that I use qualitative data collection-interviews, field observation, immersion in secondary sources, and archival research-to generate theories and hypotheses about the way in which judges and other court personnel make law in different legal cultures. ${ }^{11}$ Qualitative methods allow for the inclusion of actors' cultural understandings of institutions through the recounting of their interactions and social experience within the court. ${ }^{12}$ The limitation of this methodology, though, is that I cannot treat the small number of judges and court personnel I interviewed and observed as the full population of high court decision-makers. ${ }^{13}$ But the advantage is that the decisive role

11. The exploratory research for this Article was conducted between the spring of 2010 and the spring of 2012 under the auspices of a grant from the Mission de recherche Droit et Justice, the research arm of the French Ministry of Justice. Political scientist Pasquale Pasquino (New York University) and I carried out an empirical and comparative research project, focusing mainly on six courts: the three French courts of last resort (the Cour de cassation, Conseil d'Etat, and Conseil constitutionnel), the two European high courts (the European Court of Human Rights and the Court of Justice of the European Union), and the U.S. Supreme Court. For more details on the methodology and the data, see our final report: MATHILdE CoHEN \& PASQUALE Pas. QUINO, LA MOTIVATION DES DÉCISIONS DE JUSTICE, ENTRE EPISTÉMOLOGIE SOCIALE ET THÉORIE DU DROIT: LE CAS DES COURS SOUVERAINES ET DES COURS CONSTITUTIONNELLES [Judicial Reason Giving, Between Social Epistemology and legal Theory: The Case of Courts of Last Resort and Constitutional Courts] 13-15 (2013).

12. See Michèle Lamont \& Patricia White, National Science Foundation, [REPORT OF THE] WORKSHOP ON INTERDISCIPLINARY STANDARDS FOR SYSTEMATIC QUALITATIVE RESEARCH 10 (2005), available at http://www.nsf.gov/sbe/ses/soc/ISSQR_work shop_rpt.pdf (discussing the strength of qualitative research in exploring micro-social phenomena and actors' cultural understandings.)

13. Beginning with a few contacts at the courts under study, I recruited most of my interviewees through the contacts of previous interview subjects (a practice known as "snowball sampling"). This recruitment method is necessary in the hard-toaccess world of high courts, but is subject to a number of biases. See Patrick Biernacki 
of individuals in sustaining and transforming judicial cultures is made more apparent.

The data essentially consist of a series of semi-directive interviews with current or former judges and law clerks, as well as field notes taken to memorialize participant observations at various court meetings I attended between 2010 and $2012 .{ }^{14}$ The bulk of the data has been gathered in three jurisdictions: France, the Council of Europe/European Union, and the United States. I have studied the three French high courts (the Conseil constitutionnel, the Cour de cassation, and the Conseil d'Etat, with a particular emphasis on the latter), the two European courts of last resort (the European Court of Human Rights and the Court of Justice of the European Union), and the Unites States Supreme Court. Even though I have not included it in my case studies, throughout the Article, I occasionally refer to the U.K. Supreme Court as a reference point for a quintessential common law judicial culture.

The Article proceeds in four parts. Part I introduces the theory of deliberative democracy and its focus on high courts. I then turn to descriptions of the internal organization in place at the courts studied for this project. Part II delineates the ex ante model, typical of French and European high courts, while Part III focuses on the ex post model, exemplified by the U.S. Supreme Court. Finally, Part IV argues that deliberation at courts of last resort may be different from democratic deliberation, and that it takes place similarly, in many important ways, in ex ante and ex post courts.

\section{Are Courts Deliberative Institutions?}

\section{A. The Theory of Deliberation}

What is deliberative democracy? Deliberation in its ordinary meaning is the process by which people engage in the careful weighing of options and consequences to decide what to do. ${ }^{15}$ But what precisely deliberation means and entails for deliberative theorists is a matter of enduring controversy. Deliberative democracy commonly

\& Dan Waldorf, Snowball Sampling: Problems and Techniques of Chain Referral Sampling, 10 Soc. Methods \& Res. 141 (1981).

14. Our study involved seventeen in-depth, semi-structured interviews with current or former judges and law clerks and several days of participant observation at the Conseil d'Etat and the European Court of Human Rights. This is not in any sense a representative sample but simply a reflection of individual judges and court personnel whom we considered particularly interesting for this study and who made themselves available for interview. I supplemented this first round of interviews by conducting additional interviews during the summer of 2014 with ten more subjects (judges, staff attorneys, law clerks, and translators) at the French and European courts of last resort. The identity of the interviewees has been kept confidential. They are referred to in this Article using random letters.

15. See ARIstotle, Nicomachean Ethics 1112a30, 1112b11-16, 1139b6, $1140 \mathrm{a} 32$. 
refers to the idea that legitimate law is the result of the public deliberation of citizens. Two central themes recur in the literature. The first centers on deliberation as a democratic decision-making procedure. The second pertains to deliberation as a way of relating to one another in a democratic polity.

First, according to deliberative democrats, deliberation is superior to aggregative decision-making procedures such as the voting process that is traditionally associated with democracy. Voting proceeds from the aggregation of individual preferences concerning individual interests, leaving those preferences unchanged. Voters are sovereign; they do not need to explain or justify their choice to others or to listen to their arguments. As a result, there is no requirement that voters endorse the collectively adopted resolution or judgment as their own. By contrast, according to deliberative theorists, the process of arguing can transform people's views and produce new ones. ${ }^{16}$ A successful deliberation leads to an actual convergence of individual judgments. ${ }^{17}$ Deliberation relies on people's capacity to be swayed by rational arguments. Deliberators are exposed to new information and alternate perspectives. In the process, they hope to convince other participants of their own views, but are also prepared to take other people's judgments as grounds for revising their own.

Second, deliberation reflects a specific way of relating to others, which lends legitimacy to collective decisions. Deliberation embodies mutual respect as it requires that participants enjoy equal opportunities to influence collective decisions. According to deliberative democrats, collective decisions are legitimate if they can be the objects of a reasoned agreement among free and equal citizens. ${ }^{18}$ The deliberative ideal is based on a principle of equal participation and equal power. In order to treat each member of a deliberating group as an equal moral member, each must be afforded a part in collective decisions and each must have an opportunity to influence those decisions. In this vision, deliberation is understood as a process of mutual

16. See Gerry Mackie, Does Democratic Deliberation Change Minds? 5 Pol. Phil. \& Econ. 279 (2006) (arguing that the effects of persuasion are real albeit often latent, indirect, delayed, or disguised).

17. See, e.g., the evidence cited in Cass R. Sunstein, Conformity and Dissent (U. Chicago L \& Econ., Olin Working Paper No. 164; U Chicago, Public Law Research Paper No. 34, 2002).

18. See Joshua Cohen, Deliberation and Democratic Legitimacy, in ConTEMPorary Political Philosophy: An Anthology 143, 162 (Robert E. Goodin \& Philip Pettit eds., 2006):

In ideal deliberation parties are both formally and substantively equal. They are formally equal in that the rules regulating the procedure do not single out individuals. Everyone with the deliberative capacities has equal standing at each stage of the deliberative process. Each can put issues on the agenda, propose solutions, and offer reasons in support of or in criticism of proposals. 
justification: law and policies are legitimate to the extent that they are publicly justified to the members of the community.

Deliberative theorists acknowledge that the design of institutions can influence the potential for deliberation. Certain institutional norms are cited as fostering deliberation, such as the face-to-face gathering of individuals, insulated from the usual pressures of social interactions such as hierarchical relationships, the need to please one's constituency, or the need to make decisions under strict time constraints. While the real world of political discourse often falls short of the deliberative ideal, institutions such as high courts have been praised for approximating that ideal.

\section{B. Courts as Model Deliberators}

A number of scholars have claimed that high courts are model deliberative institutions. ${ }^{19}$ The argument is that in contrast with other branches of government, which rely on majoritarian politics, courts are responsive to moral reasoning. ${ }^{20}$ Not only do they use deliberation as a decision-making method, but they also publicly justify their decisions to citizens via published opinions. This presentation might come as a surprise given that courts have long been accused of anti-democratic tendencies. According to Alexander Bickel's famous charge, when a court strikes down a legislative act or executive action as unconstitutional, it acts in a countermajoritarian and therefore antidemocratic way. ${ }^{21}$ How have courts of last resort been transformed from a democratic anomaly into models of democratic decision-making? According to deliberative theorists, high courts' relative insulation from electoral politics may be precisely what leads them to being exemplary deliberative institutions. ${ }^{22}$ Lacking legiti-

19. See Rawls, supra note 3, at 231-40 (claiming that supreme courts are the exemplar of public reason). See also Ronald Dworkin, A MatTer of Principle 69-71 (1985) (depicting courts as "the forum of principle"); Ferejohn \& Pasquino, supra note 4 , at 22-27 (summarizing the various deliberative expectations of the different institutions of democracy); Christopher L. Eisgruber, Constitutional SelfGovernment (2001) (focusing on the link between judges' lack of accountability at the ballot box and their deliberative nature, and arguing that courts are the ideal setting for principled moral argument about public issues); Frank I. Michelman, BrenNan AND DEMOCRACY 57 (2005) (writing that "[t]he judiciary, we may think, has some institutional advantages over other branches of government when it comes to deciding philosophical questions"). But see Christopher F. Zurn, Deliberative DemocracY AND THE INSTITUTIONS OF Judicial Review (2007) (criticizing the claim that judicial opinions use the language of principled moral and political argument as an idealization); Sen, supra note 6.

20. Contra Rawls, supra note 3, at 240 (arguing that "while the Court is special in this respect, the other branches of government can certainly, if they would but do so, be forums of principle along with it in debating constitutional questions").

21. Alexander M. Bickel, The Least Dangerous Branch: The Supreme Court at the Bar of Politics 16 (1986).

22. U.S. Supreme Court Justices are appointed for life. While the judges at the other courts in question are not appointed for life, they serve relatively long terms. Judges at the Conseil d'Etat and the Cour de cassation are career judges who have 
macy at the ballot box, judges' authority must rely on another form of legitimacy, which consists in persuading the public that their decisions are the result of reasoned deliberations. Moreover, deliberative theorists claim that certain features of high courts' internal organization bestow on them special capacities for deliberation: an egalitarian culture, group decision-making, and reason-giving.

\section{Egalitarian Culture}

A basic feature of the deliberative democratic ideal is the principle of political equality, which means that each party to a deliberation should have an equal opportunity both to participate and to be heard. ${ }^{23}$ Asymmetries in power and resources undermine democratic deliberations, the argument goes, because citizens adapt their preferences to their station in society, altering their choices based on what they believe their options are rather than on the intrinsic qualities of those options. ${ }^{24}$ While strict equality in terms of socioeconomic status, knowledge, or cognitive abilities is neither always achievable nor required for a successful deliberation, equality of influence is. ${ }^{25}$ An elite should not dominate discussions. The decision should result from the deliberation of all participants, all of whom have adequate opportunities to speak, or at least equality of opportunity for different views (rather than individual persons) because of the importance that a diversity of perspectives be heard.

The egalitarian culture of high courts seems to meet this criterion. Judicial independence means that judges do not operate within a chain of command; they do not report to a supervisor. In principle, all judges have the opportunity to participate in the decision-making on equal footing. Each casts one and only one vote. Each is able to advance arguments that others might find persuasive. Moreover, judges often seem to come from similar educational and professional backgrounds, making it presumably easier for them to achieve dis-

passed a merit examination after graduate school. They typically spend most of their career at the same court, progressing by seniority (as in the Conseil d'Etat), or they are elevated from one court to the next until they reach the court of last resort (as in the Cour de cassation). Conseil constitutionnel members are selected either by the President of the Republic or the Presidents of the two houses of Parliament, and serve for one non-renewable nine-year term. As for the European Court of Human Rights and the Court of Justice of the European Union, each member state nominates a judge, whose appointment must be ratified by all the other member states, after consultation by a special committee for the Court of Justice of the European Union. European Court of Human Rights judges are appointed for a non-renewable nine-year term, and Court of Justice judges for a renewable six-year term.

23. Robert A. DaHl, Democracy and Its Critics 74ff. (1989).

24. Jon Elster, Sour Grapes: Studies in the Subversion of Rationality $109 f f$. (1983)

25. Jack Knight \& James Johnson, What Sort of Political Equality Does Deliberative Democracy Require?, in Deliberatrve Democracy, supra note 6, at 279, 280 (arguing that democratic deliberation requires equal opportunity of access to political influence). 
cursive equality. ${ }^{26}$ In the United States, the use of the expression "brethren" to describe justices sums up this aspiration to an egalitarian culture.

\section{Face-to-Face Group Discussions}

Another key assumption in deliberative theory is that parties to a deliberation not only have adequate speaking opportunities, but that they also engage in face-to-face debate with other participants. This means that deliberations should happen at a specific time, typically over a period lasting anywhere from one hour to a few days, and in a specific location where the group can physically meet. For each participant to have adequate opportunities to express her views and listen to others, deliberations should take place in small groups, comprising three participants or more. Many benefits are said to flow from group discussions in which individuals can see and hear one another, the most important being that each person is exposed to countervailing views and reasons.

Courts of last resort seem to satisfy the face-to-face group discussion criteria given that their typical review requires the collective judgment of more than one judge to avoid (or at least minimize) error by failing to correct a trial or appellate judge. ${ }^{27}$ Whether they adjudicate cases en banc or sit in panels, high court judges have generally adopted a form of conference system. ${ }^{28}$ At some point in the decisionmaking process, judges convene face-to-face to discuss the resolution of a case. Conferences take place within a more or less flexible time frame, typically lasting a few hours or, very rarely, a few days, and in a specific place-most courts include a conference room specifically dedicated to that end. ${ }^{29}$ Conferencing enables judges to collectively exchange ideas on the issues involved and, where applicable, to vote on the disposition.

26. See the op-ed by U.K. Supreme Court Justice Lady Hale, Equality in the Judiciary, THE LAWYER (Feb. 26, 2013), http://www.thelawyer.com/equality-in-the-judicia ry/3001768.article.

27. Certain courts, however, use judges sitting alone to screen cases or decide routine cases on the merits. At the European Court of Human Rights, for example, since 2010 judges sitting alone have been able to review the admissibility of applications and reject those that are plainly inadmissible. A similar procedure has been in place at the Conseil d'Etat since the 1990s. See infra notes 196-200 and accompanying text.

28. With a few exceptions, the U.S. Supreme Court and the Conseil constitutionnel hear all of their cases en banc. The European Court of Human Rights, the Court of Justice of the European Union, the Cour de cassation, and the Conseil d'Etat sit in panels of varying size depending on the importance and novelty of the case. The decision whether to retain a case before the full court or a large panel usually turns on whether the case is likely to break new ground. The more complex the case, the more judges are involved.

29. On the way in which the U.S. Supreme Court conducts its conferences, see The Supreme Court in Conference (1940-1985): The Private Discussions Behind Nearly 300 Supreme Court Decisions 3-126 (Del Dickson ed., 2001). 


\section{Reason-Giving}

Deliberative democrats claim that reason giving is an essential activity of the democratic state. ${ }^{30}$ They are often committed to a justificatory conception of democracy requiring that decisions made by the three arms of government be either acceptable or capable of being made acceptable to every individual. ${ }^{31}$ Because under conditions of freedom, people disagree about values, the argument goes, public officials ought to justify the state's action on the basis of reasons that all citizens may reasonably accept or at least understand. ${ }^{32}$ More specifically, deliberative democrats insist that judges owe a special duty to justify their decisions. ${ }^{33}$ And among judges, high court judges' reason giving is deemed to be fundamental to the political and moral legitimacy of a democracy. Two prominent representatives of this view are John Rawls and Ronald Dworkin, who respectively depicted the United States Supreme Court as an "exemplar of public reason"34 and a "forum of principle." 35

30. The centrality of deliberation to the legitimacy of democratic institutions has been explored by Amy Gutmann \& Dennis F. Thompson, Why Deliberative Democ. RACY? 23 (2004) (who note that "[w]hen binding decisions are routinely made without deliberation, the government not only conveys disrespect for citizens, but also exposes its lack of adequate justification for imposing the decision on them").

31. In last two decades, a number of philosophers have advanced a justificatory conception of liberalism. See, e.g., Gerald F. Gaus, Justificatory Liberalism: An Essay on EPISTEMology AND Political Theory (1996) (critically examining liberal political theories' reliance on various epistemologies of justification). See also Joshua Cohen, An Epistemic Conception of Democracy, 97 ETHICs 6 (1986); Amy GuTMaNN \& Dennis F. Thompson, Democracy and Disagreement (1996); Henry S. Richardson, Democratic Autonomy: Public Reasoning about the Ends of Policy (2003); Jeremy Waldron, Theoretical Foundations of Liberalism, 37 PHIL. Q. 137 (1987).

32. See, e.g., Thomas Nagel, Moral Conflict and Political Legitimacy, 16 PHIL. \& PuB. AFF. 215, 218 (1987) (arguing not only that public justification has the practical value of ensuring political stability, but also that the possibility of justifying the system to as many participants as possible is of independent moral importance); Stephen Macedo, The Politics of Justification, 18 PoL. THEORY 280 (1990) (arguing that commitments to reason-giving and reason-demanding inform some of our most valuable political practices).

33. There are a few exceptions to this judge-centric approach to democratic legitimacy. Philip Pettit, for example, focuses on legislators. See PHILIP PeTTIT, Republicanism: A Theory of Freedom and Government (1997). See also Earl M. Malz, The Function of Supreme Court Opinions, 37 Hous. L. REv. 1395 (2000) (questioning the theory that the public cares about the process of legal decision-making); Jeremy Waldron, The Core Case Against Judicial Review 115 YALE L.J. 1346, 1382 (2006) (pointing out that legislators give reasons for their votes just as judges do: the reasons are given in what we call legislative debates and they are published in the Congressional Record; the difference is that lawyers are trained to study and analyze the reasons judges give, not legislative reasoning.).

34. See RAwLs, supra note 3, at 231. See also John Rawls, The Idea of Public Reason, in Deliberative Democracy, supra note 6, at 93, 108 (asserting that "in a constitutional regime, public reason is the reason of its supreme court").

35. See Ronald Dworkin, The Forum of Principle, 56 N.Y.U. L. REv. 469 (1981) (depicting judicial review as democracy's backdrop for principled discourse). See also RONALD DWORKIN, LAw's EMPIRE 239ff (1986) (developing the thought experiment of the superjudge Hercules, “a lawyer of superhuman skill, learning, patience, and acu- 
Justices are presented as model decision-makers because they have a moral obligation-and in some jurisdictions a legal obligation ${ }^{36}$ - to provide reasons for their decisions. Supreme and constitutional courts' most obvious work products are judicial opinions-explaining and justifying decisions to litigants, other institutional actors, and the public. These opinions can be seen as the external counterpart of the internal deliberations which take place behind closed doors, arguably providing critical accountability and legitimacy to high courts. ${ }^{37}$ Opinions connect judicial decisions to prior democratic acts embodied in treaties, constitutions, or statutes, thus functioning as proxies for democratic legitimacy. Having to argue in public as well as in private, the argument goes, encourages judges to examine their own beliefs and arguments: they are expected to state their position carefully, state openly the principles they rely on, and defend them against actual and possible counterarguments. The idea is that when courts publicly articulate their reasoning, citizens will have a content-independent basis for obeying the law.

In sum, deliberations, both internal and external, are seen as key to courts' legitimacy. While certain theorists take the thesis that courts are deliberative institutions as an illustration of what they mean by the concept of deliberative democracy, others make claims

men" who is able to articulate the most coherent and principled justifications for decisions).

36. The U.S. Supreme Court is expected to explain its decisions and issue written opinions, but it is not legally required to do so. See Sup. Cr. R. 41 ("Opinions of the Court will be released by the Clerk immediately upon their announcement from the bench, or as the Court otherwise directs."). See also Edward A. Hartnett, A Matter of Judgment, Not a Matter of Opinion, 74 N.Y.U. L. REv. 123, 146 (1999) (pointing out that "the Supreme Court has no legal obligation to issue opinions"). Where the requirement is legally imposed, it may either be specific to a given court or generally applicable to all courts within a jurisdiction. The European high courts exemplify the first approach. See Treaty of Nice Amending the Treaty on European Union, the Treaty Establishing the European Communities, and Certain Related Acts art. 36, Feb. 26, 2001, 2001 O.J. (C 80) 1 (subjecting the CJEU to a statutory duty to give reasons expressed in the following terms: "Judgments shall state the reasons on which they are based. They shall contain the names of the Judges who took part in the deliberations."). See also the European Convention on Human Rights, formally the Convention for the Protection of Human Rights and Fundamental Freedoms art. 45 , Nov. 4, 1950, E.T.S. No. 5; 213 U.N.T.S. 221 ("Reasons shall be given for judgments . . .). France illustrates the second approach: there is a general, statutory mandate for all courts-private law courts, criminal courts, and administrative courts-to write opinions accompanying their decisions. See Nouveau Code DE ProCÉDURe CIVILE [C.P.C.] ART. 455; CODE DE PROCÉDURE PÉNALE [C. PR. PÉN.] arts. 485, 593, Code administratif [C. aDM.] art. 9; Conseil d'État [C.E.], Aug. 2, 1924, Dame Paquin, Rec. p. 782 (pointing out that the reason-giving requirement is a "general procedural rule which must be followed by all courts even absent a written statute" ["règle générale de procédure s'imposant même sans texte à toutes les juridictions"]).

37. See John Ferejohn \& Pasquale Pasquino, Constitutional Adjudication: Lessons from Europe, 82 Tex. L. REv. 1697 (2004) (contrasting courts' "internal" and "external" deliberations). 
about institutional design. ${ }^{38}$ This Article primarily responds to the latter, as I am mainly interested in the way in which real-world courts structure their decision processes. In the next two Parts, I propose two models of high court decision-making. The models draw analytic distinctions between ideal types rather than mutually exclusive archetypes, keeping in mind that actual courts contain a mixture of both.

\section{Ex Ante Courts}

This Part describes the internal organization of what I refer to as "ex ante courts." My primary case study comprises the French high courts-the Cour de cassation, the Conseil constitutionnel, and the Conseil d'Etat - as well as the two European supranational courts of last resort: the European Court of Human Rights (ECtHR) and the Court of Justice of the European Union (CJEU). ${ }^{39}$ I distinguish three phases in the decision-making process of ex ante courts: the individual phase of the reporting judge, the small group phase of the preconference deliberations, and the collective phase of the conference meeting.

\section{A. The Pre-conference Phase}

\section{The Reporting Judge}

Ex ante courts rely on a division of labor predicated upon the central task of a so-called reporting judge. The question of whether a court uses reporting judges is key to understanding that court's internal organization. It determines to a great extent whether or not the court's deliberation will occur prior to, during, or after the conference.

The reporting judge is the judge to whom a case is initially assigned before argument, conference, and decision. She stands as a buffer between the parties and the court, supervising the review of the record below as well as filtering the evidence where applicable. Depending on the court, cases are distributed to reporting judges in

38. See, e.g., Ferejohn \& Pasquino, supra note 4 at 22-27 (summarizing the various deliberative expectations of the different institutions of democracy).

39. A number of United States courts seem to fit the ex ante model-be it at the appellate level for federal courts, or at the appellate and supreme court level for state courts-in that they pre-assign the drafting of merits opinions to judges before cases are orally argued and discussed in conference meetings. See Daniel J. Bussel, Opinions First-Argument Afterwards, 61 UCLA L. REv. 1194 (2014) (describing the California Supreme Court's current decision-making mode as following what I would describe as an ex ante pattern). See also John B. Molinari, The Decisionmaking Conference of the California Court of Appeal, 57 CAL. L. REv. 606 (1969) (in which the author, a California justice, describes the conference system at the California Court of Appeal); George Rose Smith, The Appellate Decisional Conference, 28 ARK. L. REv. $425(1975)$ (surveying the various conference systems in place at the state supreme courts). 
rotation by the court's president, ${ }^{40}$ the panel's presiding judge, ${ }^{41}$ or a court administrator. ${ }^{42}$ At the ECtHR and the Conseil constitutionnel, a rotational system is designed to ensure an impartial method of assigning cases: all judges take turns as reporting judges regardless of seniority or expertise. At other courts, the institution of the reporting judge may correspond to a division of labor based on experience or competency. At the Conseil d'Etat and the Cour de cassation, particular judges (usually the most junior, apprentice-like judges) are assigned the reporting judge's task, while others (usually the most senior) are exempted from the task. ${ }^{43}$ Still another system is for reporting judges to be chosen based on their specific area of expertise, as is the case at the CJEU.

Asked to define the reporting judge's office, a Conseil d'Etat judge responded that:

the real job for the reporting judge, I think, is to present his position, so he writes for himself first, to explain his position and why he's proposing a given draft opinion. . . . At the same time, a good reporting judge must show what the other plausible solutions are, even if only to dismiss them. He opens and closes doors. He's not supposed to present his position only, but to explain why in the end he retains that position. ${ }^{44}$

The reporting judge's main duty is to prepare two types of internal documents before the case is argued: a memorandum ${ }^{45}$ and a draft opinion. ${ }^{46}$ The memorandum usually takes the form of an objective

40. This is the case at the Conseil constitutionnel and the CJEU. On the Conseil constitutionnel's practice, which developed under Léon Noël's tenure as court president, see Joël Boudant, Le président du Conseil constitutionnel, 103 REVUE DU DROIT PUBLIC ET DE LA SCIENCE POLITIQUE EN FranCE ET A L'ÉTRANGER [JoURNAL OF FrENCH and Foreign PUblic Law and Political ScIEnCE] 589 (1987). At the CJEU, this is codified in the RULES OF PROCEDURE OF THE CourT OF JUSTICE, art. 197, 2012 O.J. (L 265) 1, 40. See also David Edward, How the Court of Justice Works, 20 Eur. L. Rev. 539,549 (1995) (describing the allocation of cases to reporting judges).

41. This is the standard procedure at the Conseil d'Etat and the Cour de cassation.

42. This is the case at the ECtHR where case distribution is in the hands of the registrar.

43. There is an important exception to this division of labor according to seniority. When mid-level or senior judges return to their judgeship after having been assigned for a number of years to another public service post outside the court (or after having taken a leave of absence to pursue a career in the private sector), they usually serve as reporting judges upon their return to the court. In that scenario, the reporting judge could have very substantial experience both inside and outside the court.

44. Interview by Pasquale Pasquino with Judge G., maitre des requêtes at the Conseil d'Etat (June 9, 2010) (my translation).

45. That memo is called a rapport at the Cour de cassation and the Conseil constitutionnel, note at the Conseil d'Etat and the ECtHR, and rapport préalable at the CJEU.

46. Depending on the court, the draft opinion might be called a projet de jugement (ECtHR), projet d'arrêt (Conseil d'État and Cour de cassation), projet de motif (CJEU), 
essay discussing the facts and procedural history of the case, analyzing the applicable law, responding to the arguments raised in the briefs, and weighing the pros and cons of affirming or reversing. The draft opinion is oriented to the views of the reporting judge but is written impersonally, following the court's stylistic rules. To save time in case other judges do not concur in her recommendation, the reporting judge may prepare more than one draft, each premised on different legal grounds and leading to a different disposition. As a junior judge of the Cour de cassation explained, in potentially divisive cases, "one must show a sufficient flair to have prepared two drafts ... , even if initially you only had one, you were going for a reversal, and it becomes, for example, an affirmance, in that case you must have prepared in advance." 47 Once completed, the memo and draft opinion(s) are circulated to the other panel members via e-mail or through an internal electronic docket.

As will be explained below, following the English tradition, the U.S. Supreme Court remains attached to the idea that all deciding justices should inform themselves on equal terms about the cases, at least initially. ${ }^{48}$ This stands in stark contrast with ex ante courts, where each case's records and briefs go to the reporting judge only. ${ }^{49}$ Is the reporting judge system a function of a court's workload? The U.S. Supreme Court and the U.K. Supreme Court decide a relatively small number of cases yearly. ${ }^{50}$ Conversely, at courts such as the ECtHR, the CJEU, the Conseil d'Etat, and the Cour de cassation, due to ever-increasing caseloads, the reporting judge system is crucial for courts to dispose of cases in a timely manner. It permits the continuation of the collective decision-making that is characteristic of high court adjudication, but without duplicating judicial effort, given that each judge does not have the time to study the briefs and the record in every case. ${ }^{51}$

Caseload management in and of itself, however, cannot be the main reason for using reporting judges, considering that the function developed at a time when cases were sparse and has endured to this day in courts handling a small caseload, such as the Conseil constitutionnel. In France, the reporting judge's role has been formalized

or projet de décision (Conseil constitutionnel). At the Cour de cassation, the reporting judge is expected to produce a third document, the so-called avis, which is a subjective memo expressing her personal opinion on the case.

47. Interview with Judge $Q$, conseiller référendaire at the Cour de cassation (May 16,2012 ) (my translation).

48. See infra text accompanying notes 109-110.

49. But some English and U.S. courts of appeals use a form of internal organization similar to the reporting judge's function. See RUGGERo J. ALDISERT, OPINION WRITING (2d ed. 2009). Certain state supreme courts in the United States also seem to rely on a division of labor similar to the ex ante model. See, e.g., Bussel, supra note 39.

50. See infra text accompanying notes 187-193.

51. See infra Part IV.A.3. 
since the end of the thirteenth century at least. At the time, reporting judges were known as inspectores or visores inquestarum ("those who inspect or look at the inquiries") at the chambre des enquêtes, a chamber of the Paris Parlement which functioned as a court of last resort. ${ }^{52}$ Up until 1336, when they became full members of the court, reporting judges were well-read young men hired for the sole purpose of preparing cases for the judges. Because they did not work at the court, they received a bag containing the briefs, the evidence, and other records to take home. Their task was to produce what was called an "extract" (extrait) of the case as well as an opinion (judicium). The extract was a memo summarizing the parties' arguments as well as describing and analyzing the evidence. Judges used it to refresh their memories during their deliberations. ${ }^{53}$ The opinion explained which party had proven its facts best. ${ }^{54}$

The similarities between the medieval and the contemporary reporting judge are striking. The only significant difference is that historically, the reporting judge focused on sorting out and assessing the evidence, while present-day reporting judges mostly deal with questions of law. Then and now, the institution signals a bifurcated decision process, which proceeds first through an individualistic stage monopolized by one judge--the reporting judge-and later through a collective stage involving other panel members. The prevailing practice according to which the reporting judge prepares the opinion of the court before the conference, without full discussion with all his associates, has been presented as encouraging one-judge decisions and one-judge opinions. ${ }^{55}$ The reporting judge's agenda-setting power is perhaps her most significant prerogative. It gives her the opportunity to present her analysis in the best light so as to win over her colleagues. In what follows, I examine whether the system does in fact produce a one-judge decision or whether it is the informed decision of a majority of the judges who participated in the case.

\section{Small Group Discussions}

The reporting judge's ascendency has been overestimated, I think, given that the pre-conference stage is punctuated by numerous interactions with colleagues and various forms of "small group" communications which constitute pre-deliberations. I use the sociological

52. See Paul Guilhiermoz, Enquêtes et Procès, 140, 159-61 (Paris, Alphonse Picard 1892). In the seventeenth century, the function was adopted by the Conseil du $r o i$, the King's Council, which also acted as a court of last resort. See Xavier Godin, $L a$ procédure de cassation au XVIIIe siècle, 29 Historre, Économie \& SociétÉ 29 (2010).

53. See Guilhiermoz, supra note 52 , at 141 .

54. See id. at 148.

55. See Nina-Louisa Arold, The Legal Culture of the European Court of HUMAN RIGHTS 75 (2007) (noting, in the course of an ethnographic survey of the ECtHR, that "[o]nly the majority's view appears in rulings-which from my personal experience most often is the opinion of the judge rapporteur who prepared the draft"). 
and psychological concept of small group as a set of individuals united by a common task and between which direct and continuous relationships are established. ${ }^{56}$ Members of a small group interact based on their shared need to solve one or more problems. In courts where judges write their opinions from scratch, such as the Cour de cassation and the Conseil d'Etat, these small groups are by and large composed of judges only. In courts where judges have become editors rather than writers, the relevant small groups include non-judicial personnel such as law clerks, staff attorneys, and other support personnel, including translators at multilingual courts such as the European courts of last resort.

Despite the conventional picture according to which a court's collective deliberation is confined to the conference meeting, a form of small group pre-deliberation begins soon after the reporting judge has received the case file. These pre-deliberations are sometimes the result of serendipitous encounters in the court's corridors or common spaces, but more often than not they are fostered or even orchestrated by the court's internal organization. To illustrate, I pause to describe in further details the functioning of the Conseil d'Etat and the ECtHR.

\section{a. The Conseil d'Etat}

At the Conseil d'Etat, when a panel's presiding judge assigns a case to a reporting judge, she also designates another judge as the "check judge" (or "reviser," to follow the French "réviseur") for that case. Both judges are expected to commit their energies to the case, the reviser being in charge of "quality control." As a judge pointed out:

[w]ith the reviser, specifically, the idea is that collegiality is important, but collegiality is more enlightened if we have quality control at every stage. The reviser is here first to verify that the reporting judge did not make any mistake because [the reporting judge] can err, ignore a case, forget a line of precedents, misunderstand precedents. So there is this aspect of quality control, of inspection after the facts if you like. But there is also another aspect: he too [the reviser] must contribute to the debate. He must put to the test the ... reporting judge's solution ... [The reviser] might bring to the table his own solution, which can differ from the report-

56. Eloise C. Snyder, The Supreme Court as a Small Group, 36 Social Forces 232 (1958); Walter F. Murphy, Courts as Small Groups, 79 HARv. L. REv. 1565 (1966); The Psychology of Judicial Decision-Making (David Klein \& Gregory Mitchell eds., 2010). 
ing judge's. That's when it becomes interesting and why in the end collegiality becomes a form of exchange. ${ }^{57}$

The system of the check judge dates back, at least, to the 1336 Paris Parlement's Style de la chambre des enquêtes, an internal operating procedure manual aimed at judges, which recommended that the reporting judge meet with a more experienced member of the court to discuss his work before submitting it to the chambre des enquêtes, the panel of the court that was in charge of supervising the gathering of evidence. ${ }^{58} \mathrm{It}$ was also the practice, for important cases, to appoint a second reporting judge, who came to be known as "the evangelist" (évangéliste). When the reporting judge was called to present his work at the chambre des enquetes, the evangelist, acting as a sort of check judge, would second him and substantiate his arguments by reading excerpts from the depositions and other pieces of evidence. ${ }^{59}$ The use of the Christian expression "evangelist" to designate the check judge is particularly interesting given that during the same time frame, the Papal procedure for the canonization of saints became formalized as a full-blown legal trial. ${ }^{60}$ The new canonization procedure was meant to block the proliferation of heretic saints by scrutinizing applicants more strictly through an open debate. Aspiring saints began to be represented by a new curial official, the prosecutor of the cause, and the Pope, the "Promoter of the Faith," who eventually became more popularly known as "the Devil's Advocate."61 Common to the French and Papal procedures was the idea that under the guise of quality control, judges should be obliged to enter into a debate with one another. Discord and contestation were not to be avoided, but encouraged for the purpose of producing better decisions. To that end, certain judges were summoned to review and critique other judges' work.

To this day, this internal culture of disagreement persists at the Conseil d'Etat, despite an external image of consensus perpetuated by unanimous opinions. Once the reporting judge has completed her memo and draft opinion, she submits them for review, usually electronically, to the reviser. The reviser is specifically expected to play devil's advocate, looking for weaknesses, gaps, or limitations in the reporting judge's planned solution. Using an editing software or scribbling a few notes on hard copies before the first panel meeting,

57. Interview by Pasquale Pasquino with Judge G., supra note 44 (my translation).

58. See Guilhiermoz, supra note 52, at 148. See also STYLE DE LA CHAMBRE DES ENQUETES para 122 (1336), reprinted in GUILHIERMOZ, supra note 52, at 181.

59. See Gullhiermoz, supra note 52, at 149.

60. See Kenneth L. Woodward, Making Saints: How the Catholic Church DeTERmines Who BeComes a SAINT, Who Doesn't, AND Why 68 (1990) (recounting that the new procedure was introduced under the Avignon popes (1309-1377)).

61. Id. at 68 . 
the reviser may propose modifications, both minor and major. If a discord emerges between the reporting judge and the reviser, the two may meet face-to-face to discuss. Because of space constraints, the Conseil d'Etat, which has been housed since 1875 in the Palais-Royal, uses open-plan office spaces. Only the most senior judges who also have administrative responsibilities receive a private office. All other judges are lumped together in large rooms, making it easy for reporting judges to chat informally about their cases with their reviser or other colleagues. As a senior conseiller d'Etat commented, "we spend our lives together at the Conseil d'Etat."62 The reporting judge is free to reject the reviser's edits and stick to her initial drafts, but this is unlikely. Much like at the medieval Parlement, reporting judges are akin to apprentice-judges: they are usually the most junior or least experienced judges on the panel, having recently joined the court, while revisers are chosen from among the most senior and seasoned court members. ${ }^{63}$ It would thus be awkward for a reporting judge to systematically stick to her position in the face of a major disagreement with her revisers.

The function of the reviser does not exist per se at the other ex ante courts I studied for this project. But other forms of "devil advocacy" transpire under the guise of procedures designed to ensure that the reporting judge's work meets with her colleagues' pre-approval.64

\section{b. The ECtHR}

At the ECtHR, judges check the bureaucracy and are in turn checked by the bureaucracy. There are some 270 staff lawyers at the court's registry in charge of processing and preparing applications for adjudication. Registry lawyers, not judges, study case files and draft memos and proposed opinions. The reporting judge acts as a first-line supervisor, overseeing the registry's memo and draft. A registry lawyer described the pre-conference process in the following terms:

The reporting judge signs off [on the memo and draft] if he agrees. If he disagrees, he polishes [the memo and draft ], etc., and it continues [i.e., the documents go back and forth between the lawyers and the judge]. Once [the reporting

62. Interview by the author and Pasquale Pasquino with Judge Y., conseiller d'Etat at the Conseil d'Etat (Feb. 21, 2010) (my translation).

63. But see supra note 43 .

64. For instance, at the Cour de cassation, the reviser's function is allotted to the conférence, which is composed of each panel's president and most senior member. The two meet in person, without the reporting judges, to review and edit their memos, draft opinions, and avis. They share their feedback with the reporting judges and the rest of the panel electronically. Interview with Judge A., conseiller reférendaire at the Cour de cassation since 2008 (May 16, 2012). 
judge] agrees, [the case] is put on the panel's agenda, and submitted to all other judges. ${ }^{65}$

This back-and-forth typically takes place via memos or electronic communications. For particularly important cases, the junior lawyers assigned to the case, as well as more senior lawyers such as legal division heads or section registrars, meet face-to-face with the reporting judge. ${ }^{66}$ Like at the Conseil d'Etat, there is a form of engineered culture of disagreement and debate, including between judges and non-judicial personnel. According to one of the court's most senior registry lawyers, "[i]f the lawyer defends a very strong position that is in conflict with the judge's position, often [there's a debate]. Yes absolutely, some judges are very open to this and it's very lively, so it's normal."67

In addition, there exists an extra layer of "quality control" represented by the "jurisconsult" of the court and his team. These are a group of registry lawyers in charge of monitoring the case law and preventing case-law conflicts. ${ }^{68}$ I like to think of the jurisconsult as the ECtHR's "Grand Inquisitor." The jurisconsult and his delegates receive and review all draft opinions. They can intervene at any time in the writing of any opinion. During their weekly meetings, one of the lawyers may declare, "Hey, I'm reading something that fails to support 'the party line,' as we used to say during the Soviet time, that is, contrary to orthodoxy." 69 If the departure is substantial, in addition to talking to the lawyer and the reporting judge responsible for the case, the jurisconsult uses a naming and shaming technique. He includes in his weekly e-mail to all court members (including judges as well as registry members) a cautionary note on the case. If this admonition fails to elicit the desired changes, the jurisconsult can use even more drastic means, such as withdrawing the case from the panel and reassigning it to a different panel. Despite the avowed goal of preserving the coherence of the court's case law, in practice, the jurisconsult's monitoring represents a supplementary forum for debate and disagreement. Thus a member of the jurisconsult's team pointed out that "my role ... too is to say, with my team, 'Beware, if you depart from precedent, you must explain why.' One may very well have good reasons, but it must be done transparently, and really

65. Interview by the author and Pasquale Pasquino with D., staff lawyer at the ECtHR since 1996 (June 14, 2011) (my translation).

66. The ECtHR is divided into five sections, all of which have their own senior lawyers, who are known as the head registrar and the deputy registrar.

67. Interview by the author and Pasquale Pasquino with D., supra note 65 (my translation).

68. The Court created the office of jurisconsult in 2001. Since 2005, the "CaseLaw Conflict Prevention Group," a special committee composed of the President of the Court and each section's president, has met to ensure consistency in the case-law.

69. Interview by the author and Pasquale Pasquino with C., staff lawyer at the ECtHR since 1978 (June 14, 2011) (my translation). 
good reasons must be given."70 Seen from this perspective, the system is a way of furthering pre-deliberations, especially on contentious cases. The jurisconsult's weekly e-mails not only encourage the reporting judge and the registry lawyer to resume their deliberations but they also open up the discussion for the full court to chime in.

\section{The Advocate General}

For complex or sensitive cases, the CJEU and the Cour de cassation have adopted yet another form of small group pre-deliberation with the involvement of an "Advocate General" (AG). ${ }^{71}$ The Conseil d'Etat uses a similar post, known as the rapporteur public. ${ }^{72}$ At these three courts, the mission of the AG is to take a second look at cases as an impartial and independent panel member. The AG is supposed to act as a neutral third party who reviews the case from the beginning and delivers an advisory opinion. One way of describing this function in Anglo-American terms would be to compare the AG to an amicus curiae. AGs are full members of their respective courts, but they are required to argue on behalf of public welfare and the proper application of the law. Historically, they originated in the French ministerre public, a body that represented the King before the courts in the old regime.

AGs introduce an extra layer of debate at the pre-conference stage. They neither vote nor partake in the court's conference meeting; or, if they are allowed into the conference room, as occurs at the Conseil d'Etat, they are to remain silent. But they arguably play a very important role in the court's pre-deliberations. A Conseil d'Etat judge who formerly occupied the function of rapporteur public described the behavior of the latter during a panel's preliminary meetings as follows:

[T] the reviser, to the collegial debate. If he has a few ideas in mind, he can start provoking discussion, saying "OK, but I'm confused, I'm asking myself what we should do in this case, etc." He can even participate in the collegial debate. How-

70. Id.

71. The Advocate General originated in the French judicial system and is still in use at the Cour de cassation. The function has been exported to other Continental jurisdictions, as well as the CJEU. See RulEs of PROCEDURE OF THE COURT OF JUSTICE, arts. 16, 82, 2012 O.J. (L 265) 1, 12, 22. See Anthony A. Dashwood, The Advocate General in the Court of Justice of the European Communities, 2 Legal Stud. 202 (1982); Noreen Burrows \& Rosa Greaves, The advocate General and EC Law (2007); Michal Bobek, A Fourth in the Court: Why Are There Advocates-General in the Court of Justice?, 14 Cambridge Yearbook of European Legal Studies 529 (2011-2012).

72. The rapporteur public was formerly known as the commissaire du gouvernement. For the purposes of the present discussion, I will include the Conseil d'Etat's rapporteur public under the general designation of "Advocate General." 
ever, he can't vote. He never votes, he doesn't even have the right to vote. But even at this stage, he can already ask questions. ${ }^{73}$

At the Conseil d'Etat, toward the end of oral arguments, after parties have presented their case, the rapporteur public delivers an independent opinion, known as "conclusions." The conclusions identify and analyze the case law and the secondary literature, discuss the choice of options available to the court from a policy perspective, and argue for a given disposition. They could be analogized, depending on the view endorsed by the rapporteur public, to concurring or dissenting opinions. ${ }^{74}$ According to the same Conseil d'Etat judge,

[t] he rapporteur public will need to express his position and verify at the same time, somewhat similarly to the reviser, but from a different vantage point, since he will . . . conduct a third level of quality control [the first and second levels being the quality control accomplished by the reviser and that resulting from the preliminary panel meeting]. We are really talking, you know, about a chain of quality control. At the same time he starts debating, putting the solution into perspective, testing it, deciding whether he agrees or disagrees, drafting his conclusions. If he disagrees . . . he can get back to the panel, or send an e-mail, or engage in an informal discussion to say, "I disagree with such and such argument" and attempt to win over the panel. Or we all rehash and reach another solution. ${ }^{75}$

The chronology is different at the CJEU, given that the reporting judge usually begins drafting his opinion after the AG has delivered her conclusions orally or circulated them in writing in cases where no hearing has been scheduled. ${ }^{76}$ As a former law clerk recounted, "before getting started on the opinion [of the reporting judge], we generally wait for the Advocate General's conclusions." 77 The reporting judge still sets the tone for the debate. Prior to starting work on the

73. Interview by Pasquale Pasquino with Judge G., supra note 44 (my translation).

74. When there is a conflict between the court's opinion and the AG's conclusions, the conclusions sometimes influence the evolution of the case law, with counsel in future case citing them as persuasive authority, much like influential dissents in the common law tradition.

75. Interview by Pasquale Pasquino with Judge G., supra note 44 (my translation).

76. Also, unlike the sequence at the French courts, at the CJEU, when AGs deliver their opinions orally, they usually do so a few weeks after the hearing, at a public sitting of the court. See RULEs of PROCEDURE OF THE CoURT OF JUSTICE, art. 76, 2012 O.J. (L 265) 1, 12, 22.

77. Interview by the author and Pasquale Pasquino with former law clerk F. at the CJEU from 2002 to 2008 (Dec. 15, 2011) (my translation). 
case, the AG has already heard the reporting judge summarize his views during the full court's weekly meeting. The AG has also read the reporting judge's preliminary report. But the fact that the reporting judge delays drafting his opinion until after the AG has had the opportunity to present her conclusions signals that a conversation is taking place. Some CJEU commentators claim that AG conclusions have "a systematic positive influence on ECJ decisions." "78 Without going that far, I would point out that the back-and-forth between the reporting judge and the AG functions as a form of pre-deliberation in the sense that each attempts to persuade the other through the exchange of arguments and counterarguments. In that respect, AGs illustrate the way in which ex ante courts have institutionalized the mandatory consideration of alternative perspectives and points of criticism well ahead of the conference meeting.

\section{Preliminary Meetings}

In certain courts, depending on the complexity of the case, one or several panel meetings are scheduled before oral argument and conference. ${ }^{79}$ These are known as "section meetings" at the ECtHR, "general meetings" at the CJEU, ${ }^{80}$ and "preliminary meetings" at the Conseil d'Etat.81 They convene all panel members (or the full court) face-to-face to discuss cases before they are scheduled for oral argument and decision on the merits. Most judges have not studied the briefs and the records, but only briefly perused the reporting judge's documents, which are circulated in advance of the meeting, to ascertain that they are not fundamentally opposed to his plan. They discover the case through the reporting judge's oral presentation, sometimes accompanied by the reading of the draft opinion. The meeting affords the panel the opportunity to reach a consensus before the argument and the post-argument conference.

These preliminary meetings themselves are often preceded by small group pre-deliberations. In case of potential disagreement, it is considered courteous to let the reporting judge know before the meeting, be it via e-mail, phone, or in person. As a junior judge at the Cour de cassation noted, "it enables you to go see a colleague and tell him, 'There might be a problem' or 'I don't agree with you.'"82 Similarly, an ECtHR judge explained:

78. Clifford J. Carrubba, Matthew Gabel \& Charles Hankla, Judicial Behavior Under Political Constraints: Evidence from the European Court of Justice, 102 Aм. PoL. Scr. REv. 435, 449 (2008).

79. Typically the cases that make it to these preliminary meetings are the ones that raise "important" or complex issues.

80. See Edward, supra note 40 , at 552.

81. The term in French is séances d'instruction.

82. Interview with Judge A., supra note 64 (my translation). 
My system is that if I don't like what's proposed, I first talk to the reporting judge to let him know that I'm not OK [with the proposal], that perhaps we should think it through. Of course it depends on who the reporting judge is, on our personal relationship. Another option is to write a memo and to send it to colleagues well in advance, between four to five days ahead of time, attempting to persuade them that another approach would be preferable. ${ }^{83}$

Preserving the court's collegiality often requires that court members actively engage in pre-deliberation. A former CJEU clerk suggested that:

if out of the blue, without warning, a chamber . . . sends us [i.e., the reporting judge and his clerks] a memo stating that the draft opinion doesn't add up ... and suggesting an alternative version, it's really hard because we neither had the chance to inform the reporting judge that there was a problem nor to discuss and reason with the [disgruntled] colleague. ${ }^{84}$

At the Conseil d'Etat, panels convene weekly preliminary meetings to discuss non-routine cases. Each case can take anywhere from a few minutes to a few hours, depending on its complexity and the level of accord or discord among the judges. Typically, the reporting judge opens the discussion, followed by the reviser and the rapporteur public. They basically re-enact the pre-deliberation that took place in pairs for the benefit of their colleagues, with the idea that weighing the pros and cons of each approach all over again will ensure that the panel does not bring premature closure to the discussion by quickly agreeing to the first plausible solution they hear. At one of the meetings I observed, I was struck by the presiding judge's attention to the level of agreement in the room. She would consistently conclude the discussion of each case by gauging the group's readiness to find common ground:

- On this case, we are really divided ...

- Here, I have the feeling that there is a quasi-consensus for .

-For case $X$, we are more or less in agreement, right? Either way, the reporting judge's two draft opinions are ready..$^{85}$

83. Interview by the author and Pasquale Pasquino with Judge E., in post at the ECtHR since 2002 (Jan. 7, 2011) (my translation).

84. Interview by the author and Pasquale Pasquino with former law clerk F., supra note 77 (my translation).

85. Author's ethnographic field notes (Feb. 11, 2011) (on file with author). 
The reporting-judge phase multiplies opportunities for judges to disagree and critically review one another's work, with the successive intervention of the reviser, the rapporteur public, and any other colleague willing to pitch in. In comparison, preliminary meetings endeavor to build consensus. This effort can turn into heated arguments about one's voting intention, such that the meetings also serve as venues for compromises and bargaining. At the Conseil d'Etat, I noticed that the most senior judges did not hesitate to frankly express their reluctance to join an emerging majority unless the reporting judge conceded to specific modifications of the draft opinion. I witnessed a particularly telling exchange between a presiding judge-who was struggling to end a sparring match between two of the most well-respected judges on the panel-and one of those judges:

Presiding judge: "I propose that we go as is [to the oral argument and conference meetingl, and we'll see."

Judge: "Wait, I will only join the draft opinion if we clearly say [in the opinion] that the prefect must ensure compliance with environmental regulations even when acting under the Sports Code." 86

In sum, before oral argument, judges thus have multiple opportunities, if not obligations, to confer about a case and engage in small group pre-deliberations.

\section{Oral Argument}

Once an agreement has been reached on a draft opinion, the reporting judge finalizes the draft based on his colleagues' input. The case is ready for oral argument and decision. In ex ante courts, oral argument-if it takes place at all-plays a lesser role than in ex post courts. In contrast to Anglo-American courts, which still grant an important role to hearings as a mode of advocacy, ${ }^{87}$ ex ante courts rely on a mostly writing-centered legal process, reserving oral arguments for the most important or complex cases and dispensing with them for the bulk of their caseload. Significantly, until a 2008 constitutional revision, the French Conseil constitutionnel did not hold hearings at all; all cases were decided via written proceedings. ${ }^{88}$

86. Id.

87. See infra text accompanying notes 120-121.

88. Loi constitutionnelle 2008-724 du 23 juillet 2008 de modernisation des institutions de la $V^{e}$ République [Constitutional Law 2008-724 of July 23, 2008 on the Modernization of the Institutions of the 5th Republic], Journal Officiel de la République française [J.O.] [Official Gazette of France], July 24, 2008, p. 11890; Ordonnance 58-1067 du 7 novembre 1958 portant loi organique sur le Conseil constitutionnel, art. 23-10, J.O., Nov. 9, 1958, p. 129 (as modified by the Loi organique 2009-1523 du 10 décembre 2009). This constitutional revision introduced a form of concrete review (l'exception d'inconstitutionnalité) into France, meaning that the Conseil constitutionnel can now be petitioned by individual claimants to review the constitutionality of 
When no arguments are scheduled, the case goes straight to the next conference's discussion list. When they take place, oral proceedings are short, rarely lasting more than an hour. Hearings are highly solemn events, which do not lead to any real dialogue between judges and counsel. ${ }^{89}$ Judges rarely ask questions. They tend to listen in silence to counsel, who merely read their submissions. ${ }^{90}$ In courts operating with Advocates Generals, perhaps the most significant moment of oral argument is the AG's reading of her conclusions. In sum, ex ante judges do not engage in deliberations on the bench. More often than not, oral arguments are ceremonial affairs which do not play a critical role in the decision process.

\section{B. The Conference}

The conference, strictly speaking, is the moment when the judicial body (be it the full court or a judicial panel) meets with all members present to formally decide a matter. Few legal rules specify the way in which the conference is supposed to operate. ${ }^{91}$ This dearth of law on the books conjoined with the fact that meetings are confidential makes them hard to study. Except for the Conseil constitutionnel, which publicly releases verbatim transcripts of its conference meetings twenty-five years after they have taken place, the conduct of conferences remains within the domain of speculation. ${ }^{92}$ That said, through a variety of sources, it has become possible to gain insight into what goes on behind closed doors both in ex ante

statutes after their enactment. Oral proceedings were introduced as a concession to the necessary "modernization" of the legal system, allowing France to "catch up" with its European neighbors.

89. An added burden for international courts such as the ECtHR and the CJEU is the necessity for simultaneous interpretation, which interrupts and slows down the debates, thus hampering spontaneous exchanges.

90. See, e.g., Ian S. Forrester, The Judicial Function in European Law and Pleading in the European Courts, 81 Tul. L. Rev. 647, 714 (2007) (describing the CJEU's oral arguments).

91. See, e.g., Guy Canivet, Comprendre le délibéré? Ou le "mystère de la chambre du conseil", in Mélanges en L'HONNEUR de SERge GuinchaRd; JuSTICES ET DROIT DU PROCESS: DU LÉGALISME PROCÉDURAL À L'HUMANISME PROCESSUEL 205 (2010) (pointing out the lack of legal framework governing the Cour de cassation's conference meetings). Similarly, the Rules of the U.S. Supreme Court (SuP. CT. R. (2013)) omit any mention of procedures for the conference. By contrast, the European courts' rules are more forthcoming. The Rules of the ECtHR codify the conference's voting pattern. See ECrHR Rules of Court (July 1, 2014), Rule 23, available at http:/www.echr.coe.int/ Documents/Rules_Court_ENG.pdf ("The decisions of the Court shall be taken by a majority of the judges present. In the event of a tie, a fresh vote shall be taken and, if there is still a tie, the President shall have a casting vote."). The Rules of the CJEU also purport to regulate the conference proceedings. See Rules of Procedure of THE CoURT OF JUSTICE, arts. 32(3)-(4), 2012 O.J. (L 265) 1, 15 ("(3) Every Judge taking part in the deliberations shall state his opinion and the reasons for it. (4) The conclusions reached by the majority of the Judges after final discussion shall determine the decision of the Court.").

92. A first selection has been published with great fracas in LES GRANDES DÉLIBERations du Conseil CONSTitutionNel 1958-1983 (Bertrand Mathieu et al. eds., 2009). 
and in ex post courts. Former court personnel with inside knowledge such as clerks and staff attorneys have provided behind the scene accounts. ${ }^{93} \mathrm{~A}$ few judges have shared some information in memoirs, interviews, scholarly articles, public presentations, and through the publication of their personal papers. ${ }^{94}$ Finally, a handful of academics have been allowed to observe conference meetings, most famously anthropologist Bruno Latour when conducting research for his book on the Conseil d'Etat. ${ }^{95}$

Confidentiality. In principle, conference meetings are protected by secrecy. In practice, their degree of confidentiality is more a matter of organizational culture than black-letter law. ${ }^{96}$ The conference's privacy varies from court to court. At the Cour de cassation and the CJEU, no outsider may enter the room during conference, which is strictly reserved for deciding judges. ${ }^{97}$ Other courts are more open. At the Conseil d'Etat, in addition to the deciding judges, a number of individuals may be present: the rapporteur public, clerks, interns, and members of the registrar for the purpose of note-taking. At the ECtHR, the registry lawyers who worked on the case as well as translators and interpreters may join the conference meeting. ${ }^{98}$ At the Conseil consitutionnel, the secrétaire général (head registrar) attends

93. This is especially true of the U.S. Supreme Court. See e.g., Bob Woodward \& Scott Armstrong, The Brethren: Inside the Supreme Court (1979); Edward Lazarus, Closed Chambers: The First Eyewitness Account of the Epic Struggles Inside THE Supreme Court (1998). Both books claim to take the reader into the Court's behind the scene operations, relying in part on justices and law clerks as sources. Lazarus is a former clerk to Justice Blackmun and touted his book as an "eyewitness account."

94. In the United States, there is an established tradition of more or less revealing memoirs or accounts by former Supreme Court justices, e.g., Charles Evans Hughes, The Supreme Court of the United States (1928); Sandra Day O'Connor \& H. Alan Day, Lazy B: Growing Up on a Cattrle Ranch in the American SouthWEST (2002). A similar trend seems to be emerging in France. See, e.g., Dominique SchNAPPER, Une Sociologue aU Conseil constitutionnel (2010) (in which the author, a sociologist and former Conseil constitutionnel judge, recounts her experience at the court).

95. Bruno latour, The Making of Law: An Ethnography of the Conseil D'ETAT (2010).

96. The procedural rules of the ECtHR and the CJEU require that new judges and AGs appointed to the court take an oath which includes a secrecy component. Rules of Procedure of THE Court of Justice, art. 4, 2012 O.J. (L 265) 1, 10 ("I swear that I will perform my duties impartially and conscientiously; I swear that I will preserve the secrecy of the deliberations of the Court."); see also id., art. 32(1), at 14.EC THR RULES OF CoURT, supra note 91, Rule 3 ("I swear ... that I will exercise my functions as a judge honourably, independently and impartially and that I will keep secret all deliberations."); see also id., Rule 22(1).

97. The CJEU recognizes an exception for "assistant rapporteurs." These are specialists in a particular area who can be called to draft the court's judgment. They are allowed to be present during the court's conference meeting dealing with the case they helped resolve. See Rules of Procedure of The Court of Justice, art. 32(2), 2012 O.J. (L 265) 1, 14.

98. See ECTHR Rules of CourT, supra note 91, Rule 22(2). 
the conference, together with stenographers who take down a verbatim record of the exchanges. ${ }^{99}$

Purpose. The purpose of the conference is very different in ex ante and ex post courts. In ex post courts, as I argue in the next Part, the aim of the conference is to reach a decision on the disposition of the case and to assign the task of writing the majority opinion. Very little attempt is made to discuss the reasoning. In ex ante courts, the conference has a dual goal. Judges decide on both the outcome of the case and the reasons supporting that outcome. The group approves not just broadly stated arguments, but actual draft opinions, which as we have seen, are circulated to all the deciding judges beforehand. This fundamental difference explains why most of the deliberation in ex ante courts takes place before the conference. The French tradition, adopted by the European courts, is for judges to leave the conference room with finalized opinions ready to be sent to print. A senior Conseil d'Etat judge summarized the custom by declaring that "when we exit the conference room, the opinion has been approved." 100 This sometimes requires that judges edit or even rewrite opinions on the spot, as another Conseil d'Etat judge recounted:

During the conference meeting, there are several options. We adopt the draft opinion as-is or, and that's the most frequent scenario, we adopt it with modifications, or we don't adopt it. . . . In most cases, in eighty percent of the cases I would say, we enter modifications on the spot, minor ones, though they can lead to adding one word here, one word there... Sometimes this can have a repercussion on the substance, on the reasoning ... We might say "Here, we shouldn't have that argument, it's off topic." We do all this on the spot. ${ }^{101}$

Timing. The conference is usually set immediately or shortly after oral argument. It can last anywhere from a couple hours (the most frequent scenario) to a few days (in exceptional cases). ${ }^{102}$ Conference meetings are on the shorter side given that they have been preceded

99. The secrétaire général is more akin to a shadow Chief Justice than to a court administrator, as she is involved in every court decision from the preliminary stages until the final drafting. See GuIllaume Drago, ConTENTIEux CONSTITUTIONNEL FranCAIS 180 (1998) (pointing out that the function of the secrétaire general is much more than the administrative function officially granted to it).

100. Interview with Judge I., conseiller d'Etat at the Conseil d'Etat (June 30, 2010) (my translation).

101. Interview by the author and Pasquale Pasquino with Judge H., conseiller d'Etat at the Conseil d'Etat (Feb. 21, 2011) (my translation).

102. At the Conseil constitutionnel, exceptionally, the conference can be broken down into several sittings (e.g., $\mathrm{n}^{\circ}$ 81-132 DC du 16 janvier 1982, Rec. p. 18 sur la loi de nationalisation), or even days (e.g., $\mathrm{n}^{\circ} 84-181 \mathrm{DC}$ des 10 et 11 octobre 1984, Rec. p. $78 ; n^{\circ} 86-207$ DC des 25 et 26 juin $1986 ; n^{\circ} 86-208$ DC des $1^{\text {er }}$ et 2 juillet 1986 , Rec. p. $78)$. 
by pre-deliberations in the form of small group discussions, strings of e-mails, and exchanges of memoranda. By the time they sit at the conference table, participants are well-informed about the facts and the applicable law. They are prepared to adopt an opinion.

Three main reasons explain this need for pre-deliberations. First, pre-deliberations are "face-saving practices" in Erving Goffman's sense. ${ }^{103}$ They help prevent the occurrence of the social embarrassment that would result from a majority rejecting the reporting judge's proposal. To avoid that situation, as a former CJEU clerk explained, "there is really a super important pre-conference effort.... [I]t's shameful . . . if we're at the fourth or fifth draft and it still doesn't work. It's really shameful." 104 No judge wants to lose face by being disowned by his colleagues during the formal conference meeting. ${ }^{105}$ The conversations and exchanges that compose the predeliberations take place in pairs and trios where personal exchanges may be easier and more readily allow for personal camaraderie and understanding, as compared with the greater formality and interpersonal distance that larger groups often elicit. Second, predeliberations serve as a case management strategy. It is more efficient from the reporting judge's perspective to have secured a majority before the conference. Should his proposal be rejected at the conference, he would need to scrap his draft and start over again. ${ }^{106}$ Writing a new opinion from scratch would represent an increase in workload and delay the resolution of the case until the next conference meeting. Third, because of certain courts' institutional design, it may be imperative for the judicial panel to deliver an opinion on the day of the conference or very shortly thereafter. For instance, the Conseil constitutionnel works on an extremely tight schedule. By law, when reviewing statutes prior to their enactment (the so-called "a priori review"), it has one month, starting from the day it receives a petition, to issue an opinion. That time limit is extended to three months when the court engages in U.S. style judicial review (the socalled "a posteriori review" known as exception d'inconstitution-

103. Erving Goffman, Interaction Ritual: Essays in Face-to-Face Behavior 13 (Transaction Publishers 2005) (1967).

104. Interview by the author and Pasquale Pasquino with former law clerk $F$., supra note 77 (my translation). F. used the French expression "c'est la honte," which connotes a strong feeling of shame and guilt.

105. See GoFFMAN, supra note 103, at 9,12 (articulating the concept of losing face in professional, face-to-face settings and "face work," i.e., "the actions taken by a person to make whatever he is doing consistent with face").

106. The Italian Constitutional Court has an ad hoc procedure to deal with this type of situation that seems to be unheard of at the courts under review. Should the reporting judge finds herself in the minority, the president of the Italian court can reassign the opinion to a different judge. To reflect this split, the final opinion distinguishes between the giudice relatore (the reporting judge) and the giudice redattore (the writing judge. See Augusto CERRI, CoRso DI GIUSTIZIA COSTITUZIONALE 89 (5th ed. 2008). 
nalité). ${ }^{107}$ This means that the reporting judge and staff lawyers have ten or twenty days at most to draft an opinion, all the while consulting with other judges to secure a majority. ${ }^{108}$ It is thus key for the reporting judge to persuade his colleagues to join his opinion before the conference takes place.

After having described the functioning of ex ante courts as encouraging pre-deliberations, I now turn to ex post courts' internal organizational culture.

\section{Ex Post Courts}

This Part focuses on the U.S. Supreme Court, which I take as the paragon ex post court, with occasional additional examples drawn from the U.K. Supreme Court. The ex post decision-making process unfolds in three successive phases: the pre-conference case preparation and oral argument, followed by the conference meeting, and lastly the post-conference stage leading to the writing of one or several opinions.

\section{A. The Pre-Conference Phase}

\section{Certiorari}

At common law, multimember courts are supposed to be "hot" in the sense that the responsibility for the case should rest equally upon all members of the panel. ${ }^{109}$ By contrast, in so-called "cold" courts most judges lack the opportunity to familiarize themselves with the briefs and records before the case is argued, because each case is preassigned to one judge. According to the hot court paradigm, the resolution of each matter should be the result of a group effort. Every judge should read and study the briefs, perform research, and prepare memos before oral argument. The rationale behind this organization method is that all the judges should have the opportunity to obtain firsthand knowledge of a case rather than learning about it from one judge who may have already formed preconceived notions about its merits.

Ultimately, the court's temperature, to carry the metaphor further, is dependent on the existence of a reporting judge. In an ex post court, the judge assigned the task of writing the court's (or the majority's) opinion is not selected until the conference meeting. The writing judge has a fundamentally different role from that of the ex ante

107. See supra note 88.

108. See Jean-François de Montgolfier, Conference Paper: La motivation des décisions du Conseil constitutionnel, presented at the conference "La motivation des décisions des cours souveraines" ["Reason-Giving in the High Courts"], Conseil constitutionnel, Paris (June 24, 2011).

109. See Aldisert, supra note 49, at ch. 3 (distinguishing between hot and cold courts). 
courts' reporting judge, who manages a case from the very beginning and presents it to his colleagues, thus enjoying the prerogative of framing the issues. The writing judge can claim no special ownership of the case-other judges have undertaken their own study and research and remain equally involved with all the cases, at least until the conference meeting. Unlike the reporting judge, the writing judge who is subsequently designated knows the views of her colleagues before she begins drafting the court's opinion. The British Law Lord interviewed for this project had experienced both cold and hot courts, having served on the Court of Appeal (a cold court) before joining the U.K. Supreme Court (a hot court). He confided:

[M]y experience is, and most people's experience is, when there is a single judgment, particularly if someone has been nominated beforehand, there is a great tendency for the others not to study the case as well as they should. . . . I think the intellectual input is greater if you have more people doing the reading and the writing. ${ }^{110}$

What the writing judge loses in exclusivity, she gains in independence. The author of a majority opinion speaks for the majority, not for the full court or panel. She is entitled to her own writing and jurisprudential style so long as she does not deviate too much from the collective position agreed upon during the conference. Unlike the reporting judge, she need not please all of her colleagues, but only secure enough votes for a given disposition.

It is debatable whether the U.S. Supreme Court currently functions as a hot court. It might have been characterized as hot in earlier times, when each justice was personally involved in all cases, reviewing every petition that came to the Court. ${ }^{111}$ Nowadays, the Court has become "warm," at least with regard to the certiorari process. In the nineteenth century, due to their increasing workload, justices began to delegate to clerks the task of reviewing cases petitioned to the Court. Initially, each justice had his own clerks review all petitions. In 1972, under Chief Justice Burger's leadership, the Court created a "cert pool"112 to rationalize the certiorari process. Instead of letting each chamber prepare its own bench memo for each petition, it established that only one clerk at the Court would draft a memo for all nine justices. ${ }^{113}$ Justices still personally study the cases anticipated

110. Interview with Judge J., former Law Lord at the U.K. Supreme Court (March 8, 2012).

111. See Artemus Ward \& David L. Weiden, Sorcerers' Apprentices: 100 Years of Law Clerks at THe United States Supreme Court 109 (2006).

112. Ryan C. Black \& Christina L. Boyd, The Role of Law Clerks in the U.S. Supreme Court's Agenda-Setting Process, 40 Am. Pol. Res. 147 (2012).

113. See Barbara Palmer, The "Bermuda Triangle?" The Cert. Pool and Its Influence over the Supreme Court's Agenda, 18 CONST. COMMENTARY 105 (2001). Since the inception of the new system, one or more recalcitrant justices have consistently re- 
to be important or contentious. In addition to receiving the pool memos presenting a disinterested analysis of the issues, they have their own procedure for giving the petitions a second look.

Justices meet weekly in private conference to go over the latest batch of new petitions and decide which, if any, to accept. ${ }^{114}$ For a case to be accepted and placed on the docket for decision, it requires the vote of four justices. ${ }^{115}$ No law clerk or any other staff members are present at these conferences. There usually is only one go-around, with discussion and voting taking place simultaneously. For each case, following the seniority order, each justice makes a few comments and announces his or her vote. While the full Court is present to decide on cert petitions, the meeting does not constitute a forum for deliberation, given that the justices do not elaborate their reasons for admitting a case or not. If there is any discussion, it pertains to the question of whether cert should be granted, not to the merits of the case. ${ }^{116}$ Neither before nor during the cert conference, therefore, do we see much deliberation. During this phase, most of the thinking and debating takes place in small groups, within each chamber.

Over the past twenty years or so, the Court has decided on average no more than eighty cases per term, allowing it to function as a hot court once cert has been granted. After that, justices have the time to study the briefs and the record in each case. Clerks help prepare for the oral argument by writing so-called bench memos submitting the case and the arguments on all sides to analysis. Bench memos contain substantial details of fact and often a recommendation from the clerk for a decision on the merits.117 After reading the bench memos, it is customary for justices to discuss the case orally with their clerks. Justice Kennedy thus disclosed that he likes "to talk through the cases with [his] clerks," and models his interactions with them on the "discursive" exchanges between barristers and judges in England, where informal oral argument can

fused to take part in the pool. The clerks of a non-participating justice look at every petition. Currently Justice Alito is the only justice who is not part of the pool; he left it in 2008, two years after his arrival on the Court. Before him, Stevens, Marshall, Brennan and Stewart also did not take part in the pool. Adam Liptak, A Second Justice Opts out of a Longtime Custom: The Cert. Pool, N.Y. Times (Sept. 25, 2008).

114. In Court parlance, the word "conference" is used to designate both the certiorari meetings and the conferences on the merits of cases which have already been heard. For the purposes of this Article, I reserve the word "conference" for the latter and refer to the former as the "cert conference."

115. See Eugene Gressman et al., Supreme Court Practice 296-300 (8th ed. 2012).

116. For particularly important cases, it has been reported that some justices may attempt to coordinate in advance to ensure that they have enough votes to either admit or block a case. See H.W. PERry, JR., Deciding to Decide: Agenda SETTING IN the United States Supreme Court 121 (1998).

117. See WARD \& WEIDEN, supra note 111 , at 3. 
last days as the precedents are consulted and discussed. ${ }^{118}$ Justices are fully informed by the time oral arguments are scheduled.

\section{Oral argument}

Oral arguments are considerably more important in ex post courts than in ex ante courts. There is a historical reason for this, as I argue below: in the common law tradition, appellate and supreme courts mainly accomplished their business from the bench. ${ }^{119}$ In the U.K., oral argument still plays an essential role. English barristers spend a great deal of time presenting the record and the relevant case law for the judges' benefit. ${ }^{120}$ The hearing is the principal information-gathering resource for judges. The role of oral arguments at the U.S. Supreme Court is more controversial. Arguments run on twoweek blocks, followed by recesses during which the justices work on opinions and get ready for new arguments. Despite the brevity of the hour-long oral arguments, the justices are very active. They participate in dialogue with counsels in open session, rarely letting them speak for long before interrupting them with questions. These questions have an information-gathering or clarification purpose, but sometimes the justices raise new issues. ${ }^{121}$

Is oral argument a form of preliminary conference for deciding the case? It is the first time that all the justices meet face-to-face to examine the merits of a case, as the cert conference merely focuses on the appropriateness of selecting a case. Scholars of the U.S. Supreme Court and commentators disagree as to the argument's predictive effect on case outcomes. ${ }^{122}$ Justices seem to use oral arguments not only to obtain additional information from the parties, but also sometimes to engage in a dialogue with their brethren. A former law clerk, who later argued cases before the Court, gave the following account of oral arguments: "Frequently I had this happen to me: sometimes it's not an oral argument between the lawyers, it's a debate between the justices trying to persuade the justices who are undecided."123 Former Chief Justice Rehnquist described oral argument as a forum for justices to influence their colleagues' analysis and possibly sway their

118. See Stuart Taylor, Jr., When High Court's Away, Clerks' Work Begins, N.Y. Times (Sept. 23, 1988), http://www.nytimes.com/1988/09/23/us/the-law-when-highcourt-s-away-clerks-work-begins.html.

119. See infra text accompanying notes 139-143.

120. Robert J. Martineau, Appellate Justice in England and the United STATES 120 (1990).

121. Timothy R. Johnson, Oral arguments and DECision maktng on the United States Supreme Court 22-23 (2004).

122. But see id. at 122-23 (arguing based on empirical data that justices use oral arguments to gather information regarding legal and policy options in a case).

123. Interview by the author and Pasquale Pasquino with M., law clerk at the U.S. Supreme Court in 1957-1958 (Dec. 7, 2010). 
vote at the conference that will follow shortly thereafter. ${ }^{124}$ In the same vein, journalist Adam Liptak reported Chief Justice Roberts' recent declaration that "[w] hen we get out on the bench, it's really the first time we start to get some clues about what our colleagues think. So we often are using questions to bring out points that we think our colleagues ought to know about."125 In the same article, Liptak quoted Justice Kagan stating "that part of what oral argument is about is a little bit of the justices talking to each other with some helpless person standing at the podium who you're talking through."

Despite these declarations, it is hard to see a real deliberation taking place during oral arguments. Each justice seems to approach the audience in an idiosyncratic manner, without prior consultation with colleagues. One extreme example is Justice Thomas, who is famous for his nearly unbroken silence during arguments. According to him, arguments are "overrated, ... mak[ing] for a good show, but... not altogether significant in the outcome."126 To conclude, then, oral arguments are sometimes indicative of a nascent dialogue, but Justices do not openly and directly share their views on the case until the post-argument conference.

\section{B. The Conference and Post-Conference Phase}

As Supreme Court expert Bernard Schwartz notes, "[t]he decision process begins after the oral arguments when the Justices meet in conference to discuss the case."127 Justices' primary goal for the post-argument conference is to reach a collective decision on the outcome of a case, not on the rationale supporting that outcome. It is only after the conference that the articulation of reasons begins through the opinion-writing process. The conference represents a starting point for deliberations, rather than a finishing point as in ex ante courts.

\section{The Conference}

The rules of the U.S. Supreme Court say nothing about conference meetings, not even that they must take place at all. Their duration, operating procedure, degree of privacy, etc., are all left to custom and to the justices themselves to determine. As a matter of practice, the justices hold a conference during the week of an argument sitting to discuss and vote on current cases. The content of these meetings is confidential. Unlike what we have seen at certain

124. William H. Rehnquist, The Supreme Court 243-44 (2001).

125. Adam Liptak, A Most Inquisitive Court? No Argument There, N.Y. Times (Oct. $7,2013)$, http://www.nytimes.com/2013/10/08/us/inquisitive-justices-no-argumentthere.html.

126. See David G. Savage, Say the Right Thing, 83 A.B.A. J., Sept. 1997, at 54, 56.

127. Bernard Schwartz, Decision: How the Supreme Court Decides Cases (1996) (emphasis added). 
ex ante courts, the only people allowed in the room are the nine justices. Clerks are excluded.

Procedure. The standard account of the conference's operating procedure is the following. ${ }^{128}$ The Chief Justice directs the order of business, opening the discussion of every case, summarizing the facts and raising the issues. The senior Associate Justice speaks next and the sequence that ensues follows seniority. There generally appears to be no open discussion or effort to persuade others to change their views. The exchange of ideas proceeds seriatim. Participants do not debate the merits of one another's positions and do not attempt to reformulate their own views so as to make them more palatable to the group. ${ }^{129}$ The Chief Justice assigns the task of writing the court opinion on whichever side he supports. The most senior Associate Justice voting in favor of the other side assigns the minority opinion. Unlike reporting judges who have committed considerable time and energy to a case, no justice at an ex post court can claim superior knowledge of the case at this stage. As a former clerk noted, the justices "come [to the conference] all prepared. They are almost ready to write an opinion" 130 In principle, therefore, any Justice can be designated to write the Court's opinion.

Terseness. Despite variations over time, since Chief Justice Hughes's tenure (1930-1941) conferences have been notoriously short and to the point. Discussions are kept to a minimum. The conference has sometimes been described as a voting chamber rather than a forum for deliberation. ${ }^{131}$ As both Chief Justice Rehnquist and Justice Scalia have complained, the conference is less an interactive exchange of views than a succession of short statements of their position by each Justice. ${ }^{132}$ The fact that Justices often announce their vote on the case at the same time as they express the reasons justifying that vote may discourage deliberation. Indicating one's vote before hearing the reasoned analyses of one's colleagues makes

128. For this description, I rely on The SuPREMe Court IN Conference (1940-1985): The Private Discussions Behind Nearly 300 Supreme Court DecisIoNs, supra note 29.

129. In practice, it appears that no formal vote takes places at the end of the discussion of a case: each justice's vote surfaces during the go-around. See ScHWARTz, supra note 127, at 44 . Similarly, at the U.K. Supreme Court, the Law Lords apparently often forgo voting altogether. According to the Law Lord interviewed for this project, "[Y]ou don't need to have a vote. Unless somebody decides to change their mind, it's pretty clear as we go around what the result is going to be. We don't have a formal vote." Interview with Judge J., supra note 110.

130. Interview by the author and Pasquale Pasquino with L., law clerk at the U.S. Supreme Court in 2007-2008 (Dec. 3, 2010).

131. See Schwartz, supra note 127, at 85 (quoting Justice Frankfurter, who related that for former Chief Justice Hughes, "the conference was not a debating society.' When differences began to produce more heat than analysis, the Chief Justice would blow his whiskers out and say, 'Brethren, the only way to settle this is to vote"').

132. Id. at $42-43$. 
it less likely that others' views will change one's mind. ${ }^{133}$ Michael McConnell, who clerked for Justice Brennan in the 1980-1981 term and later served as a circuit judge on the U.S. Court of Appeals for the Tenth Circuit, has claimed that:

[j]udicial decision-making contains very little serious deliberation on moral issues. ...

Nor, I believe, has there been much more moral deliberation behind the curtains. The Justices are far too busy to spend much time thinking about the cases, and their conferences are largely perfunctory. Certainly they have no time to do the kind of outside reading they would need to become able to contribute to moral-political deliberation in a serious way. In contrast to the months, even years, that are devoted to major legislative deliberation, the Justices devote one hour to oral argument and somewhat less than that to discussion at conference. Amazingly, they do not even wait to see what the dissenting opinion has to say before joining the majority. The appearance of debate and deliberation created by the opinions is largely a sham. ${ }^{134}$

The Chief. The personality of the Chief Justice plays a determining role in shaping the tone and content of the conference. Some Chiefs are known for having fostered longer and livelier encounters than others. Conferences were particularly to the point under Hughes's and Rehnquist's tenures. ${ }^{135}$ Chief Justice Roberts is said to have continued Rehnquist's legacy since his arrival in 2005, though according to Justice Scalia, in an effort to promote collegiality among justices, he lets "people go on a little longer at conference."136 A former clerk questions Roberts' proclaimed efforts to foster collaboration:

I don't believe him. I think he wants to get a court that makes his judgments. The question is how fast or how slow he wants to move. I think this is a strategic question. . . . He's been the part of many opinions that reached out to de-

133. But far from impossible, of course. Justices have long been known to occasionally switch votes well after the decision conference. See, e.g., Robert H. Dorff \& Saul Brenner, Conformity Voting on the United States Supreme Court, 54 J. PoL. 762 (1992).

134. Michael McConnell, The Role of Democratic Politics in Transforming Moral Convictions into Law, 98 YALE L.J. 1501, 1536-37 (1989).

135. See ReHNQUIST, supra note 124, at 254-255, 258.

136. Quoted in David A. Yalof, Joey Mello \& Patrick Schmidt, Collegiality on the U.S. Supreme Court: An Early Assessment of the Roberts Court, 95 JUDICATURE 12, 13 (2011). But some Chiefs have been known for a more relaxed style-for instance, Stone. See SchwarTz, supra note 127 , at 86. 
cide things that they needn't decide if you really cared about unanimity. ${ }^{137}$

History. The U.K. Supreme Court and the House of Lords before it seems even less keen on collective deliberations: "After the formal hearing the members of the committee may consult informally but do not hold a formal series of meetings in the manner of other supreme courts designed to produce a collective view."138 History may partly explain why ex post courts' conference meetings are so terse. In the English tradition, appellate judges and Law Lords used to deliver their opinions seriatim from the bench at the conclusion of oral argument. The judges announced their decision without any prior consultation among themselves other than indirectly through the questioning of counsel and occasional whispering from the bench. The hearing itself was the conference. Until relatively recently, Law Lords did not conference in private before announcing their views from the bench. ${ }^{139}$ Parties and the public could literally see judges making up their minds: pausing to read documents and think in silence, taking notes, looking up precedents, reading them out loud, interrogating counsel, etc. ${ }^{140}$ One of the persistent themes in common law thinking is that justice must be seen to be done in order to be done. This oral conception of judicial accountability led to favoring speech as the dominant mode of communication in court proceedings. Each step of the litigation process was to take place in open court so that the public could observe not only the presentation of evidence and counsels' arguments, but also judges' making their decision and stating their reasons. ${ }^{141}$ According to this speech-centered legal process, if judges hid from the public eye to discuss and decide cases, a crucial aspect of judicial accountability would be missing. The government or one of their own could unduly influence them. Seriatim opinions provided assurance that each judge had done his own thinking. Thomas Jefferson, a virulent opponent of judges meeting in private conferences and delivering unanimous opinions, contended

137. Interview by the author and Pasquale Pasquino with O., law clerk at the U.S. Supreme Court in 1978-1979 (Oct. 21, 2011).

138. John Alder, Dissents in Courts of Last Resort: Tragic Choices?, 20 OxforD. J. Legal Stud. 221, 233 (2000). See also David Robertson, Judicial Decisions in the House OF LoRDS, ch. 2 (1998).

139. Interview with Judge J., supra note 110 ("All I do know is that in the 1920s, possibly before and a little after, the judges didn't even discuss what results there [were] going to be.").

140. It should also be noted that before the transformation of the judicial functions of the House of Lords into an independent Supreme Court in 2009 , judicial opinions were technically speeches addressed to the Houses of Parliament and recommending a particular result in the case.

141. Daniel J. Meador, English Appellate Judges from an American Perspective, 66 GEo. L.J. 1349, 1363 (1978) (describing the visibility of the Court of Appeal's proceedings and comparing the courtroom to a "workroom"). 
that "[t]he practice is certainly convenient for the lazy, the modest \& the incompetent."142

The Origin of the Conference. How did ex post courts come to institute conference meetings? Legal scholars point to Lord Mansfield as a pioneer. As the Lord Chief Justice of the King's Bench from 1776 to 1788 , he briefly imposed the usage for Law Lords to meet in private before delivering the court's opinion. ${ }^{143}$ But his successors returned to the seriatim practice, which persisted well into the twentieth century. ${ }^{144}$ The U.S. Supreme Court initially modeled its operating procedure on the British example. Its first decisions followed the seriatim style, ${ }^{145}$ suggesting that conference meetings may not have taken place at all. Todd Henderson argues that the Chief Judge of the Virginia Court of Appeals from 1778 to 1803, Edmund Pendleton, a Mansfield admirer, introduced to the United States the practice of judges meeting behind closed doors and delivering unanimous opinions. ${ }^{146}$ But in Virginia too, seriatim opinions were quickly reinstated after Pendleton stepped down. ${ }^{147}$ It was not until John Marshall became the Chief Justice of the U.S. Supreme Court in 1801 that the practice of conferencing was institutionalized. For judges to meet privately in order to discuss cases and negotiate a common position was still quite revolutionary at the time. ${ }^{148}$ The Supreme Court's humble beginnings encouraged conferencing. The Court did not have its own building until 1935. In the days of John Marshall (1801-1835), justices formed a close-knit community as they shared a

142. Quoted in Donald G. Morgan, The Origin of Supreme Court Dissent, 3 WM. \& MARY Q. 353, 355 (1953).

143. See M. Todd Henderson, From Seriatim to Consensus and Back Again: A Theory of Dissent, 2007 Sup. Cr. Rev. 283, 294.

144. Id. at 302. Today, Law Lords conference privately much like their American counterparts. See Alan Paterson, The Law Lords 93 (1982) [hereinafter Paterson (1982)] (noting that conferences usually last only half an hour or so, and only exceptionally have exceeded this). See also Alan Paterson, Final Judgment: The Last LAw LORDS AND THE SUPREME CoURT 87 (2013) (reporting that the Law Lords' conferencing practices have not.changed significantly since the transformation of the House of Lords into the U.K. Supreme Court in 2009).

145. The Oxford Companion to the Supreme Court of the United States 779-80 (Kermit L. Hall et al. eds., 1992).

146. See Henderson, supra note 143, at 304.

147. See Morgan, supra note 142 , at 362 :

At the close of the day's ritual, they returned to their common quarters, a boardinghouse. There, led by their benign abbot, they conversed on affairs of the day; there they interspersed between remarks about counsel and gossip of the bumptious young capital a running commentary on the cases before them. In this informal and altogether pleasant manner, they reached common agreement on decisions. Admittedly, regular consultations did take place at the court chamber, and frequently far into the evening, but these, it would appear, were auxiliary to the cheerful sessions at the dinner table or in the parlor. 304.

148. And Jefferson opposed it fervently. Cited by Henderson, supra note 143, at 
basement below the Senate in lieu of chambers during the day and a boarding house at night. ${ }^{149}$ During the Court's term, the justices thus had constant opportunities to meet and discuss cases privately. ${ }^{150}$ While this level of intimacy may be long since passed, these days lively intra- and inter-chamber deliberations occur during the postconference phase.

\section{The Post-Conference Phase}

Between the decision conference and the publication of the Court's opinion, weeks and sometimes months can go by. What goes on during that time? According to a former clerk, "nothing happens until the draft is circulated. From what I can tell, there is not a lot of talking."151 As Supreme Court observer Linda Greenhouse has pointed out, the image of the Supreme Court as a "high-level debating society," where the justices sit around and engage in endless discussions about cases is inaccurate:

Except when they are on the bench or at their twice-weekly conferences, the justices spend most of their working day alone in their chambers, or in their chambers with their law clerks. They don't pop in to one another's officers to chew over some interesting idea. Their interactions are quite formal, usually on paper. ${ }^{152}$

Unlike British judges who spend most of their time in open court conducting and deciding adversary proceedings, American justices work alone, or with their clerks. As Justice Powell famously put it, the U.S. Supreme Court operates as nine small law firms, with each justice playing the role of senior partner and law clerks that of junior associates. ${ }^{153}$ The physical arrangements of the Court encourage this state of affairs. Now that the Court has its own building on Capitol Hill, each justice enjoys her own headquarters. The word "chamber" has acquired a metaphorical meaning, designating both the team of people working with a justice and the physical location of a justice's office within the courthouse. Each chamber constitutes a microcosm, as a former law clerk suggested: "Each chamber had its own living environment. We had our own bathroom, our own closets, coffee maker, refrigerator. Some chambers were known for their better snacks." ${ }^{154}$ The chamber system isolates the justices, who only meet

149. Morgan, supra note 142 , at 362 .

150. Id. at 354 .

151. Interview by the author and Pasquale Pasquino with O., supra note 137.

152. Linda Greenhouse, 2,691 Decisions, N.Y. Times (July 13, 2008), http://www.ny times.com/2008/07/13/weekinreview/13linda.html.

153. David O' Brien, Storm Center: The Supreme Court in American Politics 122 (1986) (quoting Powell, J.).

154. Interview by the author and Pasquale Pasquino with L., supra note 130. 
face-to-face with one another during conferences and oral arguments. But does this isolation mean that no debate or group discussions take place at the Court? I argue that a form of post-deliberation occurs during the post-conference stage.

Unlike ex ante judicial cultures, which structure interactions by compelling debates between the reporting judge and other decisionmakers, the justices in ex post cultures are on their own. Writing justices do not need to account to a check judge. They do not receive feedback and requests for edits from justices who voted for the other side. They are spared the admonitions of an Advocate General. Their drafts do not run the risk of being censured by a jurisconsult. All in all, justices are far more akin to independent professionals than are their European counterparts. But it does not follow that justices abstain from engaging in mutual justification. The post-conference writing stage routinely involves small group deliberations, either intra-chamber, i.e., between a justice and his clerks, or inter-chamber, i.e., between two or more chambers.

\section{a. Intra-Chamber Deliberations}

Even when a writing justice chooses to disengage from other justices, her confinement is relative given that she remains surrounded by her clerks. A former clerk described his chamber in the following way: "[I]n a way, each six of us was an extension of him [the justice] in different ways. That's true as well of clerks for other justices."155 Often the opinion-writing is the result of a collaborative process between the justice and her law clerks. After argument, a clerk for the justice who has received the opinion-writing assignment will do more research and perhaps, depending on the justice's work methods, write a first draft. Two layers of discussion occur at the intra-chamber level: between co-clerks and between the justice and her clerks. The chamber reproduces some of the exchanges we have seen at the ex ante courts. A writing justice can play the role of a check judge with respect to the work accomplished by his clerks, when he reviews and edits the opinions they have prepared. Conversely, he can remain in charge of the first draft and require from his clerks that they play the role of a devil's advocate to test his views, much like junior Advocates General. ${ }^{156}$ Some chambers seem to function like mini-seminars, favoring group discussions:

155. Id. (the "six of us" refers to each justice's four clerks and two secretaries).

156. Alexander Bickel, who clerked for Justice Frankfurter in 1952-1953, recounted that Frankfurter demanded that his clerks contest and dispute his perspective. See Leonard Baker, Brandeis and Frankfurter: A Dual Biography 416 (1984). See also WARD \& WEIDEN, supra note 111, at 42 (quoting a Frankfurter clerk as having declared, "We regarded it as part of our job when we disagreed with him."). 
when she [the justice] would get an assignment, ... [a clerk] would draft the opinion. She would meet informally with the clerk and say "That's what I want the outcome to be. So I want it to say X, Y, and Z." But with her, it was usually pretty general and the clerks had a lot of freedom to decide how the opinion was going to be written. And then she would read the draft and make her comments in the margins. .. . We would keep going on with those drafts and she also had the practice of having us circulate our drafts with our coclerks. So the other three clerks would read the drafts and provide our feedback. ... And there were some cases when clerks would write counter-memos to the justice or would suggest [substantive changes] to the justice because there was a conflict between the clerks. ${ }^{157}$

\section{b. Inter-Chamber Deliberations}

Outside of the conference setting, justices engage in various forms of contact with one another, both face-to-face-at lunches and other social occasions or in privately arranged meetings in pairs or trios-and through the intermediary of their clerks or communication technologies such as telephone or e-mail.

The writing justice carries the burden of internal advocacy, and is instructed to write the opinion with the ultimate goal of persuading other members of the Court to accept his point of view. He can expect surprises when his draft makes the rounds for approval. The nonwriting justices may have concerns about the draft. This is the time when exchanges closest to the democratic deliberation model may take place. They will rarely change their minds, but during this period, a justice may attempt to alter the strategy or reasoning expressed by an opinion or persuade others to change their initial votes. Proposed dissenting opinions circulate as well at this time, and sometimes prove compelling enough to convert a justice who was initially in the majority. A former clerk explained, "[I]t also happens when opinions get circulated that justices will change their minds and will decide 'Well this dissent doesn't make my point or this majority doesn't make a point I want to make, so I am going to concur.'"158 Inter-chamber communications are all the more animated when the writing justice believes that she may be short by one vote. By contrast, if she is confident that she can rely on a solid majority, there may be no discussion at all. Another clerk reported:

157. Interview by the author and Pasquale Pasquino with K., law clerk at the U.S. Supreme Court in 2002-2003 (Nov. 29, 2010).

158. Id. 
If you don't have to hang onto a vote, or if it doesn't really matter, then you write it the way you think. ... And then the draft is circulated among the Court. People sign and send back slips saying count me in, or I dissent, or can you change this? That's done with little slips of paper, which is the first page of opinion folded into thirds. ${ }^{159}$

Post-conference discussions do not seem to take place face-to-face most of the time, but rather through communications mediated by clerks or the exchange of memos. A clerk thus recounted: "There was some communication in person but that was rare. They [the justices] would rather send memos rather than e-mail. They would have their clerks type the memo and then send it." 160 Another clerk pointed out that if there is an active inter-chamber discussion during the opinionwriting stage, "mostly it is done from clerks to clerks and then up to the justice. So you are writing this and you go to Justice S.'s clerk and you would say: 'I think I have to handle it this way. What would your boss think if I did this?" 161 In their book on the Supreme Court, Artemus Ward and David Weiden have called this form of communication the "clerk network."162 Law clerks get to know other clerks and gather information about other justices' thinking and writing process. They report back to their justice who can adjust her own thinking and writing accordingly. The clerk network is so crucial to the Court's internal organization that it affects clerk hiring. According to a former clerk, his justice "really wanted people who would be good emissaries among the clerks. . . He wanted people who could really function well among the clerks." 163 As a result, this justice insisted on hiring politically moderate clerks who could easily get along with clerks from other chambers. ${ }^{164}$

To conclude, ex post courts do not seem to deliberate much before or during the oral argument and the conference. They do engage in post-deliberations during the opinion-writing stage, but do these exchanges amount to deliberations in the sense favored by deliberative theorists? The next Part compares the deliberative theory with actual judicial practices at both ex ante and ex post courts.

159. Interview by the author and Pasquale Pasquino with O., supra note 137.

160. Interview by the author and Pasquale Pasquino with K., supra note 157.

161. Interview by the author and Pasquale Pasquino with O., supra note 137.

162. See WARD \& WEIDEN, supra note 111 , at 4, 160 (arguing, at 4, that "[d]uring the voting and coalition-formation stage, clerks act as informal ambassadors across chambers and make recommendations based on information they get through this 'clerk network."').

163. Interview by the author and Pasquale Pasquino with L., supra note 130.

164. Id. 


\section{Pre- ANd Post-deliberations}

So far the goal of this Article has been to present two organizational cultures. Based on this account, the question now is whether courts of last resort are internally deliberative in the sense favored by deliberative theorists. This Part claims that high court judges do much of the work imagined by the deliberative theory model, but not within the bounds of the conference that is typically assumed to exemplify the deliberative effort. Justices "pre-deliberate" or "postdeliberate" rather than simply deliberating. Most of the decisionmaking occurs through multiple forms of contacts and interconnections within small groups, including non-judicial personnel, rather than in full court or full panel face-to-face encounters.

\section{A. Falling Short of the Deliberative Ideal?}

This section outlines three ways in which high courts may diverge from the deliberative ideal delineated in Part I: (1) decisionmakers are not always on an equal footing, (2) collective face-to-face meetings are relatively rare events, and (3) docket pressure sometimes interferes with full-fledged deliberations.

\section{Lack of Equal Participation}

The deliberative ideal is based on a principle of equal participation, according to which every participant's perspective should be taken into account because it is valuable in and of itself. Courts differ from polities in that they do not necessarily aspire to being internally democratic. Their goal is not primarily to reflect the views of all those involved but to get the right answer, measured against standards which are usually outside the debate itself. As a result, not every court member's views deserve equal respect and consideration. Some are considered worthier than others, for example because they are more in line with precedents or reflect a specific form of expertise. In that sense, courts are elitist not because judges are unelected but because they constitute a professional environment revolving around expert knowledge. This knowledge-based differentiation goes hand in hand with various forms of inequalities between the individuals who take part in court decisions. The institutional design and organizational culture of high courts create differential levels of status between judges, on the one hand, and between judges and other court personnel, on the other hand. These differences mean that those who participate in the decision will not always have equal opportunities to influence the outcome. More specifically, authority relations may disturb the cooperative and egalitarian nature of the decision process, be it by virtue of real hierarchies, functionally differentiated assignments, or differences in experience or expertise. 
At four of the six high courts discussed in this Article (the U.S. Supreme Court, the Conseil constitutionnel, the ECtHR, and the CJEU), a non-hierarchical organization of judicial personnel is in place. All judges are hired on the same terms and share the same employment status. There is one qualification, though. Courts of last resort are presided over by chief judicial officers, be they known as the "Chief Justice," the "President," or the "Vice-President."165 Theoretically, a court's chief judicial officer is only primus inter pares (first among equals), not a superior to whom other judges must report. ${ }^{166}$ The chief should enjoy no special privilege in influencing case outcomes, having only one vote in the conference, just like the other judges. ${ }^{167}$ However, in practice, as noted earlier, chiefs do not lack opportunities for leadership. ${ }^{168}$ Their agenda-setting role gives them the upper hand in framing the issues, given that they preside over conference discussions, where they open the debate before the other judges have the opportunity to speak. ${ }^{169}$ Through their administrative functions-such as the authority to choose the reporting judge or the writing judge-they wield special influence in the conference and other inner workings of the court. Naturally, the style of leadership varies from chief to chief, with some being more controlling than others, e.g., playing a dominant role during conference and leading the discussion toward their preferred outcome. ${ }^{170}$

In contrast, the Conseil d'Etat and the Cour de cassation openly rely on a hierarchical organization, as different types of judicial tenure tracks are in place. Distinctions exist between junior and senior judges in employment terms, salary, title, and sometimes even decision-making abilities. For instance, the Cour de cassation includes two main categories of membership:171 senior judges, known as "heavy councilors" (conseillers lourds), who are fully tenured mem-

165. Some courts also have deputy presidents (e.g., the U.K. Supreme Court) or vice presidents (e.g., the CJEU and ECtHR), in addition to a president.

166. Regarding the Chief Justice of the United States, see SchwarTz, supra note 127, at 74 (reporting that Justice Frankfurter once wrote that the Chief Justice is emphatically not "the boss" of the Court).

167. This is not the case at the Conseil constitutionnel, where the President does have the decisive vote. See Const. art. 56 (Fr.).

168. See supra note 129 and text accompanying notes 128-131.

169. At courts where cases are decided by panels rather than by the full court, the court's President may not participate in every decision. In that scenario, the panel's presiding judge endorses an agenda-setting role.

170. At the U.S. Supreme Court, famous examples of "heavyweight" chiefs include Justices John Marshall and Earl Warren. In France, President Robert Badinter was known for systematically winning his colleagues over to his views. See MAURICE Faure in conversation with Christian Delacampagne, D'une République à L'autre: Entretiens sur L'histoire et SUR LA POLITIQUe 129 (1999).

171. In addition, the Cour de cassation has also begun recruiting a few judges from outside the judiciary, based on their specific expertise, e.g., trade unionists, academics, and high-ranking civil servants. They hold the title of conseillers en service extraordinaire. 
bers of the court; and apprentice-like judges, the conseillers référendaires, who come from the regular judiciary and are placed on a temporary assignment in the court. ${ }^{172}$ The conseillers référendaires are dispatched to one of the court's chambers and assume the functions of reporting judges. While they attend all of their chamber's conference meetings, they are only allowed to vote on the cases which they personally reported. In all other cases, they are allowed to contribute to the collective discussion but prohibited from casting a vote.

Even where there is no hierarchy among court members, the internal organizational culture may lead to an imbalance of influence. The effective contribution of individual judges varies from case to case regardless of how well they justify their views to one another. For instance, the division of labor between the reporting judge or the writing judge, on the one hand, and the rest of the panel, on the other, can bestow an advantage on the former. Panel members may be particularly susceptible to framing effects given that they are less likely to conduct their own independent research when a case has been pre-assigned to a reporting judge. ${ }^{173}$ The reporting judge's indepth familiarity with the details of the case, and sometimes also with the area of law, allows her to present the issues in a way that favors her preferred disposition. ${ }^{174}$ In ex post courts, the writing judge may have the upper hand on an opinion not so much because she enjoys a cognitive advantage but rather due to strategic considerations. So long as she can maintain a sufficiently strong coalition, she can shape the breadth and depth of the opinion through her choice of arguments. An imbalance of influence can also result from factors such as the sequence in which participants speak during the conference. Some courts use an order determined by seniority (i.e., with the court's presiding judge and the most senior judge leading off) and others by inverse seniority (with the most junior judge speaking first). Either sequence could either undermine or further equality, depending on whether we think that age is a proxy for authority or that the person who speaks first or last exerts greater influence.

172. The conseillers référendaires are entry-level or mid-career lower court judges, who can serve for a maximum of ten years. Though they must leave the court after that, they are given priority status to reenter the Cour de cassation as conseillers lourds later in their career. A similar system exists at the Supreme Court of Japan. See Masako Kamiya, “Chôsakan”: Research Judges Toiling at the Stone Fortress, 88 WASH. U. L. Rev. (Special Issue: Decision Making on the Japanese Supreme Court) 1601 (2011).

173. For two seminal articles on framing effects, see Amos Tversky \& Daniel Kahneman, The Framing of Decisions and the Psychology of Choice, 211 Science 453 (1981); Amos Tversky \& Daniel Kahneman, Rational Choice and the Framing of Decisions, 59 J. Bus. S251 (1986).

174. That explains why ex ante courts have built-in bias-alleviating safeguards such as check judges, Advocates General, jurisconsults, preliminary meetings, etc. See supra Part II. 
In addition to these differences among judges, there also exist important asymmetries between judges and the non-judicial personnel who participate in the decision process. According to the deliberative theory, all participants in a deliberation should have equal opportunities to influence the outcome, or at least have the ability to participate in the deliberation on equal terms. But who should be counted as the relevant deliberators in high courts? In courts where staff lawyers or clerks take an active part in the decision-making process it would be disingenuous to maintain that judges are the sole decision-makers. Courts decide cases through small groups which have permeable boundaries. These small groups may include judges who are not members of the deciding panel, staff attorneys, clerks, interns, translators, and other support personnel. ${ }^{175}$ At the U.S. Supreme Court, the CJEU, and the ECtHR, where clerks and registry lawyers play a major research and writing role, non-judicial personnel are clearly involved in deliberations. Clerks and lawyers are often included-if not in charge of-the initial decision to admit a case, the preliminary research, the drafting of opinions, and the negotiation with other chambers. Their contribution is problematic from the perspective of deliberative theory, however, because they do not enjoy decision-making equality with judges. Even though they participate in myriad ways in the decisionmaking process and contribute to the reasoning that carries the day, they are denied the formal authority to decide cases. They are not even considered members of the deliberative body. Significantly, they are never allowed to vote in any of the courts reviewed here, and are excluded from the deliberation room at the CJEU and the U.S. Supreme Court. At the ECtHR, registry lawyers routinely attend conference meetings, but their difference in status is marked in multiple ways, from their seat assignment to the fact that they may only speak if called on by the judges.

Deliberative democracy grounds its legitimacy in part on deliberators' capacity to justify their views to one another rather than on their status, numbers, or other arbitrary advantages. An occasional imbalance of influence among judges does not necessarily reflect a failure of the model of democratic deliberation so long as it is consistent with the demand that all think about the matter and come to a conclusion. That the non-judicial personnel involved in courts' decisions lack the ability to participate in deliberations on equal terms, however, is a clearer departure from the model.

175. While U.S. Supreme Court Justices and CJEU judges have law clerks specifically attached to their chambers whom they hire personally, the interns, legal assistants, and staff lawyers at the three French courts of last resort and the ECtHR are selected bureaucratically by ad hoc committees. The CJEU and the ECtHR also employ a number of translators who are usually also lawyers in their own right and may have a role in shaping the substance of a judgment. 


\section{The Disappearing Conference}

Face-to-face meetings have long been considered both the norm and the most effective mode of communication for groups to discuss problems and make decisions within organizations. As we have seen, high courts have been depicted as havens for these types of exchanges. In particular, the conference, which convenes all deciding judges in quiet seclusion, is thought to epitomize the virtues of these face-to-face meetings. The conference, however, has too often been assumed to be the most significant step in the decision-making process. The assumption is that the conference has a direct effect upon the decision: minds are changed, minority views become majority views, and vice versa. However, as Parts II and III have shown, the deliberative importance of the conference has been overstated, in both ex ante and ex post courts.

In ex ante courts, the conference is an end point. By the time they get together in the privacy of the conference room, the judges have already pre-deliberated in small groups. In ex post courts, the conference is a starting point. It is only after stepping out of the conference room that judges begin to deliberate in small groups. In both judicial cultures, the conference remains a forum for decision-making, but not so much for deliberating. In ex ante courts, the conference serves to confer a collective stamp of approval on an opinion prepared by a sub-group of the panel. In ex post courts, the conference serves to determine a majority in favor of a disposition and to assign the writing of opinions. Ultimately, most of the actual thinking, talking, persuading, negotiating, refining, polishing, etc., takes place either before or after the conference.

The face-to-face component of deliberations is also missing from much of the courts' interactions. Part of this is due to the peculiar culture of certain courts and part is due to technological advances. To some extent, the CJEU and the U.S. Supreme Court eschew face-toface communications between judges as a result of their reliance on the clerk network. ${ }^{176}$ Rather than meeting one-on-one or in small groups to discuss cases in person, judges often rely on their clerks to conduct informal exchanges of ideas across chambers. As a former CJEU clerk recounted, "very often it [the pre-conference discussion on draft opinions] occurs through clerks. When relationships are good-that's why we spend so much time lunching and partying together-it's fantastic because you can just give someone a ring saying 'Can I drop by?' and everything happens in a collaborative manner." 177

176. On the U.S. Supreme Court's reliance on clerks for inter-chamber discussions, see supra text accompanying notes $160-163$.

177. Interview by the author and Pasquale Pasquino with former law clerk F., supra note 77 (my translation). 
More fundamentally, over the past thirty years, mediated exchanges through communication technologies and online interactions have become commonplace in collaborative work. Just like other organizations, high courts have taken advantage of this technological progress. Bernard Schwartz noted twenty years ago that the acquisition by the U.S. Supreme Court of its first Xerox machine in 1969, followed by word processors and computers had the effect of reducing personal exchanges both in conference discussions and in the postargument decision-making process. ${ }^{178}$ At all six courts studied for this Article, judges are now able to exchange documents rapidly and to interact through electronic means using e-mail, electronic dockets and databases, file-and-application sharing, group decision support systems, electronic bulletin boards, real-time calendar and scheduling systems, and occasionally teleconferencing. It is so much easier to send drafts and memos and to give feedback electronically, that mediated exchanges often supplant other forms of face-to-face meetings or even telephone conversations.

How does online deliberation compare with face-to-face deliberation? The effects of computer-mediated deliberation are still debated. ${ }^{179}$ Some researchers are skeptical, arguing that online discussions are less effective than face-to-face discussions. ${ }^{180}$ Others claim that the invisibility associated with mediated interactions reduces inhibitions and facilitates contributions to the discussion by all members. ${ }^{181}$ This equalizing effect would increase the likelihood that members who disagree with the dominant analysis or more generally are of unequal status express their views. ${ }^{182}$ This may occur because face-to-face communications are more cohesive and personal. ${ }^{183}$ Electronic technologies attenuate some social cues and

178. Schwartz, supra note 127 , at 41.

179. See Seong-Jae Min, Online vs. Face-to-Face Deliberation: Effects on Civic Engagement, $12 \mathrm{~J}$. Computer-Mediated Comm. 1369, 1372 (2007) (pointing out that very few empirical studies so far have compared the effect of online deliberation with that of face-to-face deliberation).

180. See, e.g., Boris B. Baltes et al., Computer-Mediated Communication and Group Decision Making: A Meta-Analysis, 87 Organizational Behavior \& Hum. DeCISION PROCESSes 156 (2002) (arguing that computer-mediated communication leads to decreases in group effectiveness, increases in the time required to complete tasks, and decreases in member satisfaction compared to face-to-face groups).

181. See Sara Kiesler, Jane Siegel \& Timothy W. McGuire, Social Psychological Aspects of Computer-Mediated Communication, 39 AM. Psychologist 1123 (1984); Susan G. Straus, Getting A Clue: The Effects of Communication Media and Information Distribution on Participation and Performance in Computer-Mediated and Faceto-Face Groups, 27 Small Group Research 115 (1996); Ilze Zigurs, M. Scott Poole \& Geraldine L. DeSanctis, A Study of Influence in Computer-Mediated Group Decision Making, 12 MIS Q. 625 (1988).

182. Robert S. Baron et al., The Eyes Have It: Minority Influence in Face-to-Face and Computer-Mediated Groups, 82 J. ApPLIED PsycholOGY 706-18 (1997).

183. See David H. Jonassen \& Hyug II Kwon, Communication Patterns in Computer Mediated Versus Face-to-Face Group Problem Solving, 49 Educ. Tech. RES. \& DEv. 35 (2001) (presenting a study suggesting that face-to face interactions tend to 
therefore mitigate the impact of status differences and subgroup memberships on participation dynamics. ${ }^{184}$ Beyond that, as Seana Shiffrin has suggested, courts' reliance on mediated communication may reduce some of the deliberative disadvantages of face-to-face contact, including the distortions introduced when parties' tempers flare, when one party bullies and the other resists, and when some judges' egos preclude a public turnabout. ${ }^{185}$ From that perspective, some measure of indirectness (via e-mail or paper communication) or mediation (through clerks) may help establish or reestablish deliberative equality among decision-makers of different statuses. ${ }^{186}$

To sum up, high courts may be the backdrop to deliberations, but many of the conversations and exchanges that compose the mutually justificatory activity take place outside of the conference room: in small groups, electronically, or through intermediaries. That is not to say that face-to-face contact is lacking, but that it is not primarily found in the conference. Rather, judges accumulate face-to-face contact over multiple cases and the passage of years, allowing for sustained conversations and a sense of mutual accountability that transcends the conference setting.

\section{Caseloads}

Until now, I have paid little attention to courts' workload. But the deliberative ideal lacks verisimilitude for certain courts by virtue of their skyrocketing dockets. Given their crushing workloads, judges at the ECtHR, CJEU, Conseil d'Etat, and Cour de cassation cannot possibly have the time and resources necessary to engage in collective deliberation in any but the most important cases. In 2012, the Cour de cassation rendered an astonishing 11,983 judgments on the mer-

follow a linear sequence of interaction, with participants reflecting more on general ideas and perspectives in reaching their decisions, while computer-mediated groups are more task-oriented and structured).

184. Vitaly J. Dubrovsky, Sara Kiesler \& Beheruz N. Sethna, The Equalization Phenomenon: Status Effects in Computer-Mediated and Face-to-Face Decision-Making Groups, 6 Hum. COMPUTER INTERACTION 119 (1991); Andrea B. Hollingshead, Information Suppression and Status Persistence in Group Decision Making: The Effects of Communication Media, 23 Hum. Comm. REs. 193 (1996); Lee Sproull \& Sara Kiesler, Reducing Social Context Cues: Electronic Mail in Organizational Communication, 32 MGMT. SCI. 1492 (1986).

185. This suggestion derives from Seana Shiffrin's response to a previous version of this Article presented at the 2014 Comparative Works-in-Progress Workshop held at UCLA.

186. But it is too soon to draw any definite conclusion here, given that much of the existing psychological research is still tentative and not specifically tailored to the court setting. The typical experimental setting, which involves one-time deliberations by participants who do not know one another on subjects in which they are not experts, is a far cry from court deliberations comprising legal experts accustomed to working together. Also, what communication scientists call "online deliberations" are deliberations exclusively conducted online rather than a mixture of small group meetings and e-mail exchanges. That said, some of the conclusions may nonetheless be relevant for the court setting. 
its, ${ }^{187}$ closely followed by the Conseil d'Etat with $9,131,{ }^{188}$ the ECtHR with $1,678,{ }^{189}$ and the CJEU with 595 judgments. ${ }^{190}$ During that time, by contrast, the Conseil constitutionnel decided 203 cases, ${ }^{191}$ the U.S. Supreme Court issued 78 opinions, ${ }^{192}$ and, for another point of comparison, the U.K. Supreme Court delivered 43 judgments. ${ }^{193}$ To be sure, courts with the greatest caseloads also count more judges. The Conseil constitutionnel and the U.S. Court both have nine judgeships, whereas the Cour de cassation comprises about 163 judges, the Conseil d'Etat averages 200, the ECtHR has 47, and the CJEU 28.

Despite these size differences, the ratio of cases per judge remains significantly higher at certain courts than at others. Is it feasible for courts flooded with petitions to fully deliberate each case? Variations in caseload partly stem from voluntary choices. Certain courts have devised ways of reducing their caseloads. Others prefer to keep their dockets intact even if it means that they need to resort to separate tracks to handle cases. A major divide concerns the process of screening cases. The basic trade-off is between, on the one hand, deciding more cases at the cost of resorting to abbreviated forms of deliberation for a subset of those cases and, on the other hand, deciding fewer cases, but with more deliberative resources available for each. The U.S. Supreme Court has chosen the latter path, and has long embraced discretionary jurisdiction. ${ }^{194}$ With a few exceptions, it freely selects the cases it wants to hear. Petitions denied cert are disposed of with minimal judicial deliberations; only those selected by

187. See Cour de CASSATION, RAPPORT ANNUEl 2012: La PREUVE DANS LA JURISPRU. DENCE DE LA COUR DE CASSATION, 514-15 tbls.1-8 \& 1-9 (2013), available at http:// www.courdecassation.fr/TMG/pdf/rapport_ccassation_2012.pdf. This figure is extrapolated from the Cour de cassation's statistics by subtracting from the civil and criminal cases terminated in 2012 those which were not decided on the merits, because they were withdrawn, not admitted (procédure de non-admission), dismissed on procedural ground, etc.

188. Conseil d'État, Le Conseil d'État et la JUSTICE adMinistrative en 2012 at 9, available at http://www.conseil-etat.fr/bilan-activite2012/data/catalogue.pdf.

189. ECTHR, ANNUAL REPORT 2012 at 152 (2013), available at http://www.echr.coe .int/Documents/Annual_report_2012_ENG.pdf.

190. Court of Justice of the European Union, Press Release No 23/13, Statistics Concerning Judicial Activity in 2012: Consolidation of the Results Achieved in Recent Years (Mar. 6, 2013), http://curia.europa.eu/jcms/upload/docs/application/pdf/2013-03/ cp130023en.pdf.

191. Bilan statistique au 30 décembre 2012, Nouveaux Cahiers du Conseil constitutionnel, no. 39, Apr. 2013, http://www.conseil-constitutionnel.fr/conseil-constitution $\mathrm{nel} / \mathrm{francais} /$ nouveaux-cahiers-du-conseil/cahier-n-39/bilan-statistique-au-30-decem bre-2012.136901.html.

192. Judicial Business of the United States Courts, AnNual Report of the Director, tbl.A-1 (2013).

193. The Supreme Court Annual Report and Accounts 2012-2013 at 33 (2013), available at http://www.supremecourt.uk/docs/annual-report-2012-13.pdf (U.K.).

194. Since the Supreme Court Case Selections Act of 1988, Pub. L. No. 100-352, 102 Stat. 662 (codified at 28 U.S.C. $\S 1257$ ), Supreme Court justices have had almost absolute control over their workload. See also Bennett Boskey \& Eugene Gressman, The Supreme Court Bids Farewell to Mandatory Appeals, 121 F.R.D. 81 (1988). 
the Chief Justice or flagged by one of the justices make it to the "discuss list" during the cert conference. ${ }^{195}$ Petitions granted cert, however, are afforded the full (post-)deliberative treatment described in Part III.

By contrast, the ex ante courts studied in this Article have retained mandatory jurisdiction. In theory, all properly presented complaints must be adjudicated. This means that every person filing a petition is, in principle, entitled to a decision on the merits. In practice, though, courts under high docket pressure have resorted to screening cases. For instance, the ECtHR has adopted "filtering" mechanisms to dismiss applications on a growing number of grounds. ${ }^{196}$ In addition, a three-judge committee, rather than the standard seven-judge section, now decides so-called "repetitive" cases. ${ }^{197}$ They are expedited with minimal discussion between the registry lawyer, the reporting judge, and the two other judges, who basically rubber-stamp the proposal. As an ECtHR judge commented, "at the committee level, things move very fast. This is what increased the Court's output."198 Other courts such as the Conseil d'Etat or the Cour de cassation have embraced similar case management schemes to weed out "easy" cases for fast-track resolution by either judges sitting alone or three-judge panels. ${ }^{199}$ A Conseil d'Etat judge thus recount: "[W] sion was made by a judicial panel comprising nine people. Nowadays half of our decisions are made by judges sitting alone."200 Only cases considered as "hard" or "important" are resolved through a process

195. Minimal judicial deliberation does not mean minimal judicial attention, though. As mentioned at supra notes 112-113 and accompanying text, each petition is addressed by at least one "pool memo" (or sometimes more than one, if a justice does not participate in the "cert pool" and requires that his clerks individually review all petitions), which is circulated among the chambers and marked up. See PERRY, supra note 116 , at $51-58$.

196. Since 2010, ECtHR judges sitting alone have had the authority to declare an application inadmissible, which sometimes involves an examination of the merits of the case. See Protocol No. 14 to the Convention for the Protection of Human Rights and Fundamental Freedoms, amending the control system of the Convention art 7, Council of Europe, opened for signature May 13, 2004, C.E.T.S. No. 194 (entered into force June 1, 2010).

197. The ECtHR defines an application as repetitive if it pertains to "issues which have already been the subject of Court decisions and therefore should have been resolved by the respondent member States." See ECTHR, ANNUAL REPORT 2012, supra note 189 , at 47 (speech given by Thomas Hammarberg).

198. Interview with Judge O., judge at the ECtHR since 2008 (July 8, 2014) (my translation).

199. This case management system, called the procédure d'admission des pourvois en cassation (PAPC), has been in use since 1987. See Loi 87-1127 du 31 décembre 1987 portant réforme du contentieux administratif [Law 87-1127 of Dec. 31, $1987 \mathrm{Re}-$ forming Administrative Law] art. 11, J.O., Jan. 1, 1988, pp. 7, 8.

200. Interview with Judge I., conseiller d'Etat at the Conseil d'Etat (June 30, 2010) (my translation). 
involving the full range of small group pre-deliberations described earlier.

Through various methods, therefore, courts confronted with a high volume of cases adapt their practices to avoid overflow. Deliberation has become an expensive use of time, a scarce resource. Courts ration it, reserving it for the few cases viewed as deserving of the court's full array of mutually justificatory activities. A seasoned Conseil d'Etat judge summarized this approach using a clothing industry metaphor. In her words, every application admitted is directed toward one of three judicial panels: three-judge panels, which, as she put it, specialize in "ready-to-wear garment," nine-judge sections for "tailor-made work," and eighteen-judge sections or the full court for "haute couture."201

The growing dockets of courts of last resort play a decisive role in the structuring of their internal organizational cultures. There is an inevitable tension between courts' aspirations to make decisions based on deliberation and their need to dispose of their caseload in a timely manner. As a result, if high-caseload courts do deliberate, they tend to do so selectively or through expedited procedures. Thus, only a subset of their caseload is decided through fully deliberative procedures.

\section{B. Opinions}

So far, I have focused on high courts' inner workings rather than on their outputs, i.e., judicial opinions. What is the relationship, if any, between a court's internal organization and its opinions? This Article rejects "deductive institutionalism," i.e., the idea that reasoned opinions necessarily reflect reasoned deliberations. ${ }^{202}$ Instead, I am inclined to think that there is a reciprocal influence between a court's institutional design and the style of its opinions. My hypothesis is that the style and form of judicial opinions condition a court's work methods as much as those methods inform opinion-writing. Further research should be done to elaborate this hypothesis, but for now I will briefly outline and illustrate it.

Typical ex ante opinions follow the single judgment approach: the court issues a single authoritative judgment, speaking with one voice. Opinions are not signed by their individual author, the reporting judge. They must meet a host of formal requirements both in terms of presentation and reasoning, following a constraining format consisting of separate parts covering the issues, facts, law, law application, and the disposition of the case. ${ }^{203}$ Following the Continental

201. Author's ethnographic field notes (May 18, 2012) (on file with author).

202. GuTMANN \& ThOMPSON, supra note 30 , at 45 .

203. For instance, the structure of ECtHR judgments is mandated by the Court's Rules. See ECTHR RULes of CourT, supra note 91, Rule 74. 
tradition, judges tend to use hypertechnical language and repetitive expressions, making it difficult for the general public to understand what is being said. ${ }^{204}$ More importantly for our purposes, individual votes are usually not disclosed, even though the judges may have been deeply split on a particular issue. The opinion makes little or no pretense to tracking the judges' actual internal decision-making process. The judges present a seemingly united front, which is in fact made up of distinct and individual contributions. If there have been any disagreements among judges, they are hardly visible in the public arena. The ECtHR allows separate opinions, but the majority opinion is considered the judgment of the court. Tellingly, dissenting or concurring judges are merely permitted to "annex"205 their separate opinions to the court's judgment. ${ }^{206}$ Separate opinions do not add to the judgment as in the U.K. or U.S. Supreme Courts, where the court's ratio sometimes needs to be extracted from several opinions. ${ }^{207}$

U.S. Supreme Court opinions exhibit different qualities. In spite of considerable variations, they are discursive, open-textured, and longer compared to ex ante judgments. Justices claim authorship and responsibility for their portion of the writing. The style of individual justices is idiosyncratic in a way that is unparalleled in ex ante courts, where judgments adhere to a template and are sometimes specifically reviewed for stylistic consistency. ${ }^{208}$ The justices enjoy great expressive and rhetorical freedom, occasionally resorting to figurative or humorous language to explain their reasoning. Opinions

204. For instance, the French and European courts introduce successive paragraphs with the phrases "Considérant" ["Considering"] or "Attendu que" ["Given that"]. See Mitchel De S.-O.-L'E. Lasser, Judicial Deliberations: A Comparative Analysis of Judicial Transparency and Legitimacy (2004) (describing the French judicial style, in particular that of the Cour de cassation).

205. See ECTHR Rules of CourT, supra note 91, Rule 74(2) ("Any judge who has taken part in the consideration of the case by a Chamber or by the Grand Chamber shall be entitled to annex to the judgment either a separate opinion, concurring with or dissenting from that judgment, or a bare statement of dissent.")

206. See Robin C.A. White, Judgments in the Strasbourg Court: Some Reflections 4-5 (working paper, SSRN-id 1435197), available at http://ssrn.com/abstract=14351 97 (arguing that the presentation of ECtHR judgments fundamentally differs from common law judgments, where each opinion stands on its own and readers are responsible for figuring out what the court's decision is).

207. See Pamela C. Corley et al., Extreme Dissensus: Explaining Plurality Decisions on the United States Supreme Court, 31 Just. SYs. J. 180 (2010) (analyzing the causes of the U.S. Supreme Court's plurality decisions where the Court is unable to generate a single opinion that is supported by a majority of the justices.)

208. The CJEU thus has a team of lecteurs d'arrêt (judgment readers), who are often French or Belgian national judges in charge of editing and polishing the court's judgments, erasing any stylistic deviation. The ECtHR recently created a similar unit for its most important opinions, but like the Conseil d'Etat and the Cour de cassation, it owes much of its stylistic unity to its staff's acculturation with the prevailing norms rather than enforcement by a policing unit. ECtHR Registry lawyers, much like the Conseil d'Etat and the Cour de cassation's junior judges, are trained in the court's opinion-writing style upon their arrival at the court. 
reveal, to some extent, the court's internal decision-making process. The court's public discourse is often visibly split, especially in cases with high ideological stakes, such as those involving questions of rights and liberties. This is not to say that ex post opinions are candid and fully mirror judges' discussions and background negotiations. ${ }^{209}$ By and large, ex post justices openly acknowledge their disagreements, but refrain from divulging the compromises and quid pro quo that took place behind closed doors.

In sum, ex ante and ex post courts present us not only with divergent ways of making decisions, but also with different schemes for justifying them. The style of opinions may have affected the courts' internal organization as much as their internal organization may have shaped their style of opinions. We can imagine several possible channels of reciprocal influence between high courts' opinions and their modes of deliberation.

\section{When the Style of Opinions Affects a Court's Internal Culture}

Ex ante courts. The required façade of unanimity in ex ante cultures may increase the sense of collaboration among judges. More specifically, as we have seen, the need to issue a unanimous (or seemingly unanimous) opinion causes judges to pre-deliberate before the conference. When judges know that they will be called upon to sign a common opinion by the end of the conference meeting, they probably feel a strong incentive to begin discussions ahead of time. If they failed to do so, they would run the risk of partially surrendering their decision-making authority to the reporting judge. As a senior judge at the Conseil d'Etat stressed, "[t]he wording of the opinion must be approved by the judicial panel in its entirety. . . . [T] he draft is read collectively and approved collectively." ${ }^{210}$ There is no time for indepth discussion, negotiation, and rewriting at the conference table. Judges eager to see their viewpoints taken into account need to persuade their colleagues beforehand.

Ex post courts. We can conjecture that when judges are individually responsible for explanations, they are disinclined to predeliberate. There is little impetus for U.S. justices to pre-agree or negotiate before the conference; the writing judge has not yet been picked, so there is not much to consult about. As we saw, in an ex ante court, the most promising means for a dissenting judge to make his voice heard is to influence the wording of the court's opinion. By contrast, in an ex post court, a justice does not need to transact with

209. I have argued elsewhere, however, that judges cannot and should not be held to a requirement of candor. See Mathilde Cohen, Sincerity and Reason Giving: When May Legal Decision-Makers Lie?, 59 DEPAUL L. REV. 1091 (2010).

210. Interview with Judge I., supra note 200 (my translation). 
her colleagues: she can always voice her disagreement by writing separately. But there might be multiple incentives to collaborate with others and engage in persuasion efforts after the conference meeting. For example, a writing justice might want to engage in post-deliberations when the majority coalition is fragile or when she is hoping to garner wider support for her theory. Justices change some of their votes, they ask clerks to find out more about why their colleagues on the bench have balked or what the significance of another justice's argument is, and through this process, the language in opinions is refined.

\section{When a Court's Internal Culture Affects Opinion-Writing}

Ex ante courts. The effect of pre-deliberating as a group can be the production of a line of reasoning that is hard to follow. The reporting judge alone is initially responsible for the handling of the case. But as discussed above, other decision-makers become involved early in the process. Those can be, depending on the court, a check judge, the Advocate General, the jurisconsult, staff lawyers, clerks, and translators. This first round of feedback often causes the reporting judge to revise her draft. A second round of editing follows. Once the draft opinion has circulated among the full panel and a majority has emerged, multiple participants are encouraged to make their views known. Members of the minority influence the wording of the opinion as much as members of the majority, sometimes even more so. ${ }^{211}$ Ultimately, no one individual judge bears sole responsibility for the draft, which goes through many hands and may integrate multiple and sometimes conflicting points of view. This effort to reach a consensual solution and to include as much feedback as possible in the reasoning is often reflected in confused and obscure opinions. ${ }^{212}$

Ex post courts. Justices' custom of post-deliberating naturally has repercussions on opinions. Ex post judicial cultures shy away from a norm of consensus, a feature that manifests itself in split decisions. It may be that U.S. Supreme Court opinions have become highly divided in the past decades partly because the conference discussion has atrophied. In the U.K., "the prevailing ethos on these matters in the House of Lords [forerunner to the Supreme Court] is that of laissez-faire. By and large, it is up to the individual Law Lord whether he writes or not, and whether he dissents or not."213 As

211. See Edward, supra note 40, at 556 (noting in regards to the CJEU that "[t]he minority are not excluded from the deliberations of the majority, nor do they have any interest in excluding themselves since they may yet be able to swing the majority towards their point of view or at least attenuate what they find objectionable").

212. See e.g., André Tunc, La Cour de cassation en crise, 30 ARCHIVES DE PHILOSOPHIE DU DROIT 157, 165 (1985) (observing that collegiality imposes judicial compromises which are "less clear" and a "source of ambiguity").

213. Paterson (1982), supra note 144, at 108. 
noted above, there is little collective face-to-face deliberation that could lead to the possibility of the sorts of concessions and accommodations required for the Court to speak with a more unified voice. When they do occur, these concessions and accommodations tend to be mediated and to take place after the conference. The current Chief Justice of the U.S. Supreme Court, Justice Roberts, seems to think that the Court's conferencing style has an impact on opinions. A few years ago, he declared that he would strive as Chief Justice to instill a more collegial culture at the Court in order to produce less fragmented opinions. ${ }^{214}$

The precise nature of the interaction between institutional design and the style of opinion remains an area for further exploration. In particular, it would be useful to clarify the relevant factors-be they pre- or post-deliberations, the need for unanimity, or the entrenched style of judgments.

\section{Conclusion}

This Article has proposed two models for thinking about the way in which high courts structure their collective reasoning. I have argued that the internal organizational culture of courts of last resort may present institutional obstacles to deliberation in the sense championed by deliberative democrats. That is not to say that courts of last resort do not deliberate. Ex ante courts pre-deliberate, while ex post courts post-deliberate. In both cultures, important judgments are the result of multiple decision-making stages in the form of successive mini-deliberations through small group, interpersonal communications. That the components of deliberation happen in small groups does not make the deliberation any less of a mutually justificatory activity if we understand the democratic ideal to be one of mutual justification, an acknowledged obligation to be responsive to other parties' reasons, and a greater manifest openness to being influenced by the arguments of others.

However, the democratic model of deliberation fails to account for some of the specific constraints faced by high courts, such as the involvement of participants of different statuses in the decision-making process, the production of legal knowledge based on expertise that is not equally shared by all, and the need to balance caseloads against deliberative expectations. That said, courts' internal organizational cultures have established expectations of elaborated and articulated mutual justification and created opportunities for and an openness to persuasion, negotiation, and compromise. Even when the conversations and exchanges that compose the mutually justificatory

214. See Jeffrey Rosen, Roberts's Rule, AtLantic Monthly (Jan. 1, 2007), http:// www.theatlantic.com/magazine/archive/2007/01/robertss-rules/305559/ (interviewing Chief Justice Roberts). 
activity are reduced or expedited, or involve unequally situated participants, the organizational cultures guarantee if not quality decision-making, then at least consideration of multiple viewpoints. In this sense, I second deliberative democrats' argument that processes matter. High court judges are not any less inclined to hide their own biases, ideological preferences, and interests behind a screen of principle and legalese than anyone else, but their decisionmaking procedures are formalized in a way that may help eliminate some of these subjective factors-namely, through pre- and postdeliberations. 
1008

[Vol. 62 